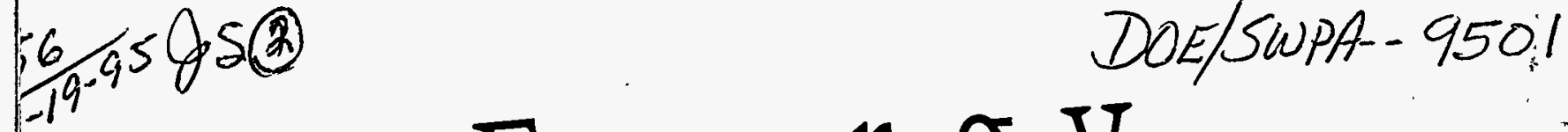

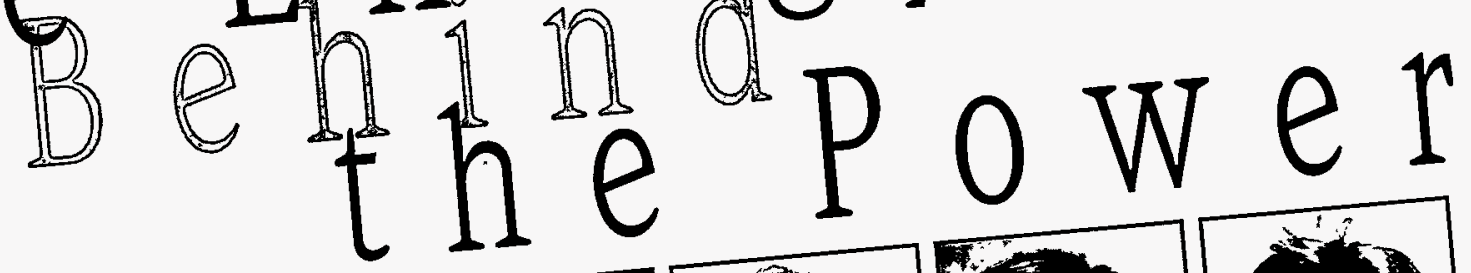
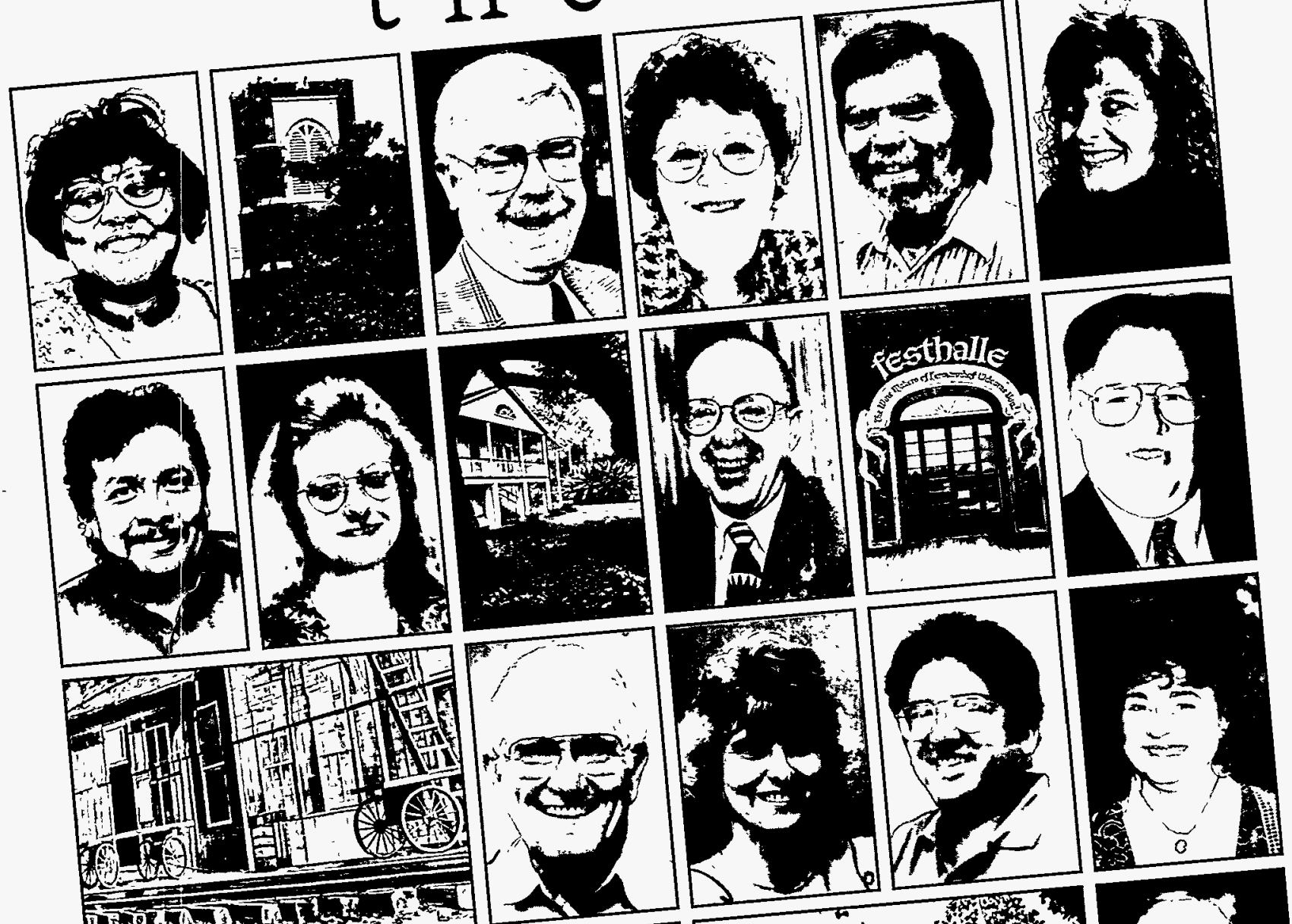

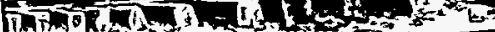
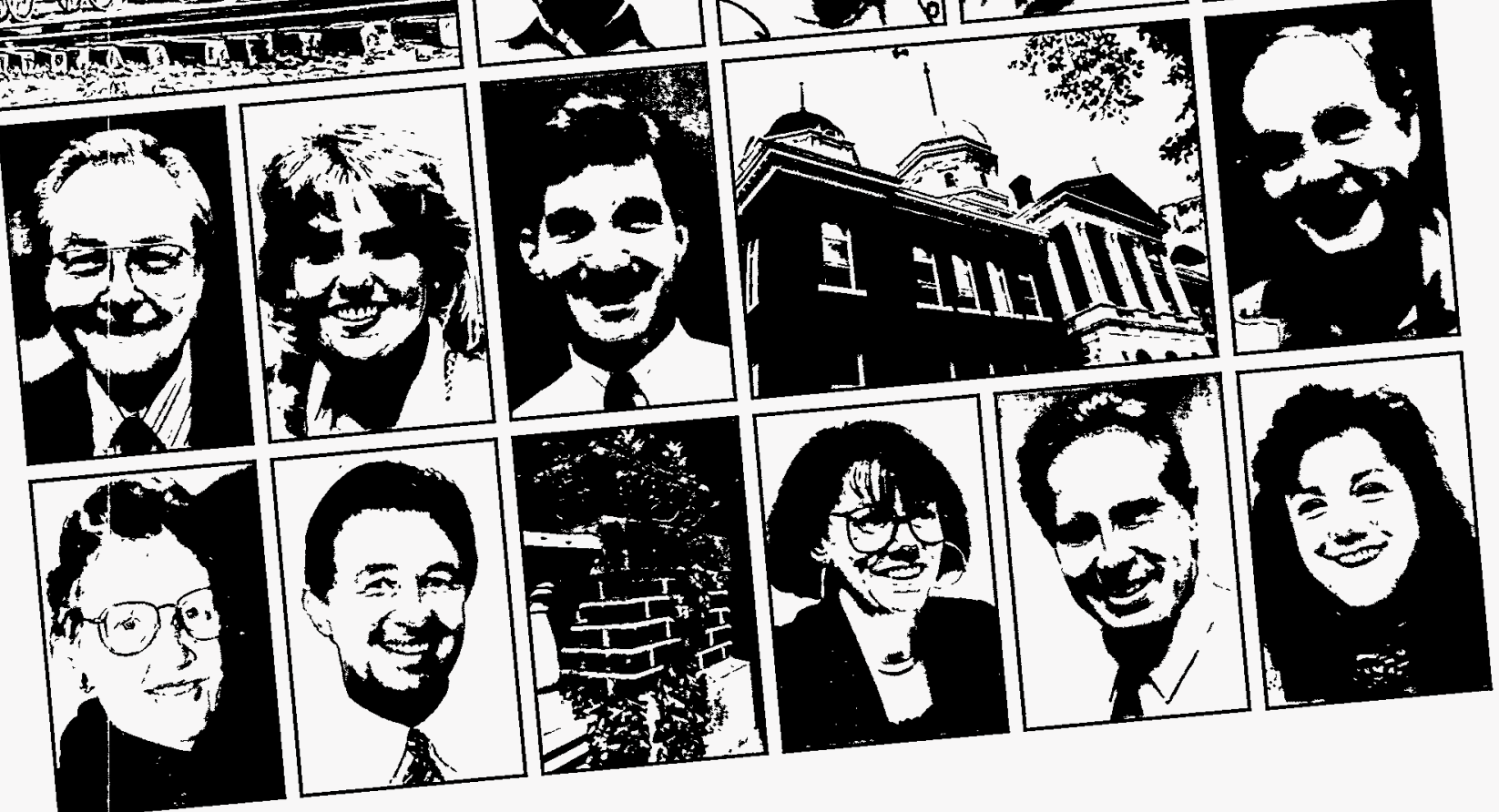

SOUTHWESTERN POWER ADMINISTRATION 1994 ANNUAL REPORT 


\section{On the Front Cover}

Top Row (L to R)

Second Row

Third Row

Fourth Row

Fifth Row

Priscilla Guesby

Charles Wells

Juan Nichols

Gerald Elmore

Nadine Griffin

Terry Helton

Coralee Patrick

Stephanie Mullins

Carolyn Reece

Jennifer Penny

Rick Thomas

Jim Pendergrass

Jan Blase

Steve Gore

Diane Essary

Joe Brady

Chuck Terrill

Sandy Stockwell

Bob Johnson

Martin Griffin

Paula Spreer

Sherrie Devine

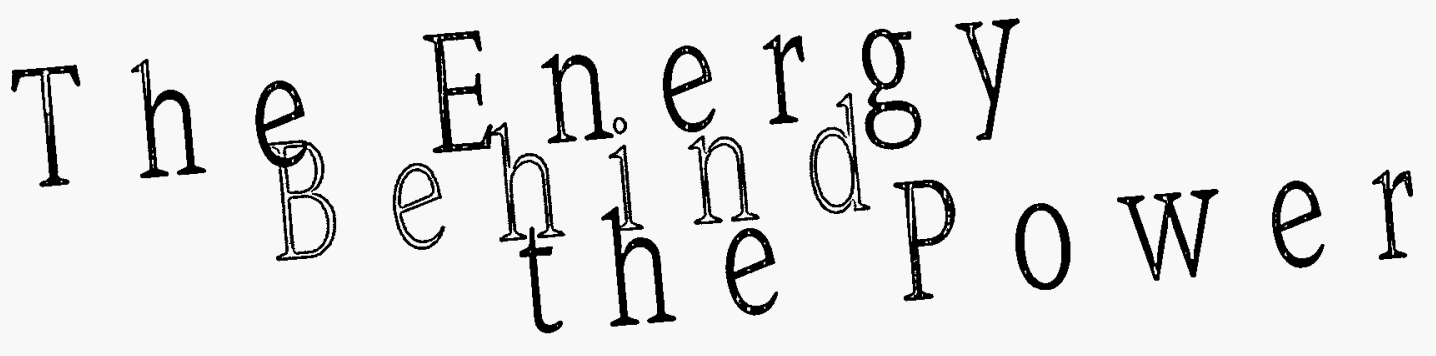

\section{On the Back Cover}

Top Row (L to R)

Second Row

Bruce Stephens

Debbie Johnson

Ken Gibbon

Darrell Phillips

Bruce Graham

Debbie Robinson

Judy Rodgers

Chip Taylor

Carolyn Glidewell

Darrell Phillips

Third Row
Debra Hensley
Leon Eck
Sharon Whitehill
David Reichenberger
Terry Flanagan

Fourth Row

Mike King

Jack Atkinson

Jim Donahue

Terry Flanagan
Fifth Row

Joe Ticheli

Karla Meyer

Regina Smith

Dan O'Brien

Rhonda Davis 


\section{DISCLAIMER}

Portions of this document may be illegible in electronic image products. Images are produced from the best available original document. 
This 1994 Annual Report is dedicated to Southwestern's customers.

As you read this report, you will have the opportunity to meet several of them. They represent all six states in our region: Arkansas, Kansas, Louisiana, Missouri, Oklahoma and Texas. You will be introduced to them and to the unique communities in which they live and serve. In one story, you will even meet "customers of a customer," those individuals who unknowingly rely on Southwestern's power in their day-to-day lives.

Take a few minutes to meet these folks. And be sure to look at the faces on the cover, also. They are all our friends, our business associates. They are

"The Energy Behind the Power."

\section{DISCLAIMER}

This report was prepared as an account of work sponsored by an agency of the United States Government. Neither the United States Government nor any agency thereof, nor any of their employees, makes any warranty, express or implied, or assumes any legal liability or responsibility for the accuracy, completeness, or usefulness of any information, apparatus, product, or process disclosed, or represents that its use would not infringe privately owned rights. Reference herein to any specific commercial product, process, or service by trade name, trademark, manufacturer, or otherwise does not necessarily constitute or imply its endorsement, recommendation, or favoring by the United States Government or any agency thereof. The views and opinions of authors expressed herein do not necessarily state or reflect those of the United States Government or any agency thereof. 


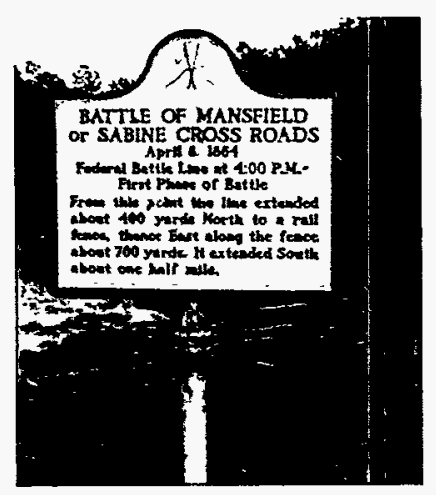

\section{Table of Contents}

Letter to the Secretary 1

Overview 2

Mission Statement 2

Southwestern Federal Power System 2

Section 5, Flood Control Act of 1944

Map of Southwestern Federal Power System 3

Financial Statement Presentation 4

Performance Measurements $\quad 4$

National Performance Review $\quad 4$

Year in Review 5

Southwestern Federal Power System
Financial Statements

Performance Measurements 34

Summary of Results $\quad 40$

Financial and Statistical Data 43

Southwestern Power Administration Organization 51
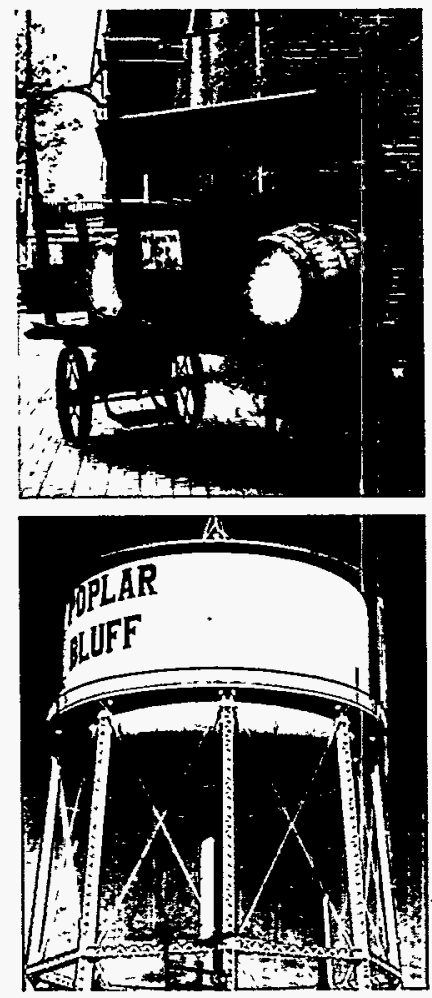
Honorable Hazel R. O'Leary

Secretary of Energy

Washington, D. C. 20585

\section{Dear Madam Secretary:}

As Fiscal Year 1994 ended, Southwestern Power Administration saw another above-average year in hydropower generation with 6,939 gigawatthours of energy produced. Southwestern collected revenues totalling $\$ 109.4$ million which allowed $\$ 32.2$ million to be repaid on Federal investment, raising the total cumulative repayment to $\$ 329.9$ million.

As a Federal Power Marketing Administration, our responsibilities are more diverse and multi-faceted than ever before. The coordinated operation of our system of hydroelectric power projects continues to produce optimal benefits to the region we serve. Our involvement in water resource management means that we are committed to balancing our customer obligations with the needs of other water users. We are involved with many groups region-wide to ensure that our interests are best served for our customers while also being aware of and involved in the complex issues and requests of others.

Our effective use of "energy banks" again this year has produced a net deposit of $104,569,000 \mathrm{kWh}$. Energy banks offset hydrologic conditions and allow us to reduce the amount of energy purchases during more costly hot weather conditions. Most importantly, our use of energy banks allows us to help maintain the lowest rates for our customers.

The needs of our customers, who depend upon us for their hydroelectric power and energy, are of utmost importance to us. We are ensuring that those needs will continue to be met with the numerous equipment replacements we made this year to maintain and enhance our system. We also are near completion with the construction of our new Supervisory Control and Data Acquisition/Energy Management System which will assure our system's continued reliability.

Early in the year, Southwestern's management focused on reviewing the Agency's Strategic Plan which we first developed three years ago. Realizing that dynamic organizations are affected by changing issues and priorities, we believed it was vital to review and, if necessary, revise our existing plan. We were pleased to find that with this assessment, our vision remained clear and few changes were necessary.

We are also continuing our TOM (Total Quality Management) journey with vigor. We are well into our Stephen Covey training on principle-centered leadership and will continue to offer the training to all of our employees. We are focusing our efforts on organizational and process measurements, benchmarking and expanded customer surveys to assure that we know what our customers truly expect.

The theme of our 1994 Annual Report illustrates Southwestern's appreciation of our customers - "the energy behind the power." We are pleased to have been able to serve them for more than a half century, and we take special pride in the significant benefits Southwestern has brought to the rural economy in our region. As an organization with a great responsibility to serve our customers, Southwestern is looking wholeheartedly toward the future and the challenges it holds.

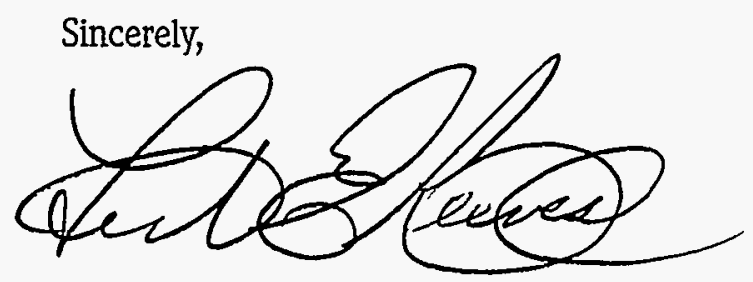

Forrest E. (Gene) Reeves

Acting Administrator 


\section{Mission Statement}

The primary purposes

of Southwestern are

to market Federally

generated hydroelectric

power, operate a reliable

and safe transmission

system, and encourage

energy efficiency

for the benefit of the

region. All of this is

accomplished by

professional, courteous,

customer-oriented

people.

\section{The Southwestern Federal Power System}

The Southwestern Federal Power System encompasses the operation of 24 hydroelectric power plants by the U.S. Army Corps of Engineers and the marketing of power and energy from those plants by Southwestern Power Administration of the U.S. Department of Energy.

To integrate the operation of these hydroelectric generating plants and to transmit power from the dams to its customers, Southwestern Power Administration (Southwestern) maintains 2,220 kilometers (1,380 miles) of highvoltage transmission lines, 24 substations, and 46 microwave and VHF radio sites. Southwestern's headquarters are in Tulsa, Oklahoma; its dispatch center is in Springfield, Missouri; and its maintenance crews are based in Jonesboro, Arkansas, in Gore and Tupelo, Oklahoma, and in Springfield, Missouri. Three offices - Power Marketing and Delivery, Maintenance and Administration and Rates - are responsible for meeting Southwestern's mission.

Twelve of the 24 generating plants are scheduled directly by Southwestern, and a total of 19 contribute to the interconnected system operations. Generation at the five remaining projects (Denison, Narrows, Sam Rayburn, Whitney and Willis) is used to serve specific customer loads.

At the end of fiscal year 1994, Southwestern marketed power and energy to 10 generation and transmission cooperatives, one distribution cooperative, three military installations, 41 municipal utilities, and three municipal utility joint-action agencies. One of the joint-action agencies has its own allocation of power from Southwestern; the other two serve 34 municipal utilities to whom Southwestern has allocated power. The total number of power allocation customers is 92 . Additionally, excess energy is occasionally sold to non-allocation utilities.

\section{Section 5, Flood Control Act of 1944}

Section 5 of the Flood Control Act of 1944 as set out in Title 16 U.S.C.A. Section $825 \mathrm{~s}$ sets forth the mission of Southwestern Power Administration, which was established in 1943.

Electric power and energy generated at reservoir projects under the control of the Department of the Army and in the opinion of the Secretary of the Army not required in the operation of such projects shall be delivered to the Secretary of Energy who shall transmit and dispose of such power and energy in such manner as to encourage the most widespread use thereof at the lowest possible rates to consumers consistent with sound business principles, the rate schedules to become effective upon confirmation and approval by the Secretary of Energy.

Rate schedules shall be drawn having regard to the recovery (upon the basis of the application of such rate schedules to the capacity of the electric facilities of the projects) of the cost of producing and transmitting such electric energy, includ- 
ing the amortization of the capital investment allocated to power over a reasonable period of years. Preference in the sale of such power and energy shall be given to public bodies and cooperatives. The Secretary of Energy is authorized, from funds to be appropriated by the Congress, to construct or acquire, by purchase or other agreement, only such transmission lines and related facilities as may be necessary in order to make the power and energy generated at said projects available in wholesale quantities for sale on fair and reasonable terms and conditions to facilities owned by the Federal Government, public bodies, cooperatives, and privately owned companies. All the monies received from such sales shall be deposited in the Treasury of the United States as miscellaneous receipts.

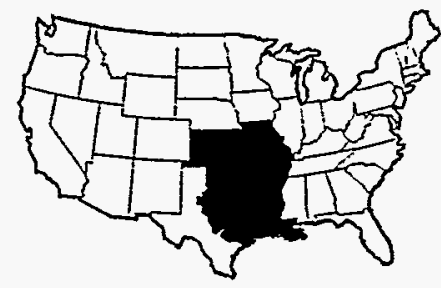

\section{Southwestern Federal Power System}

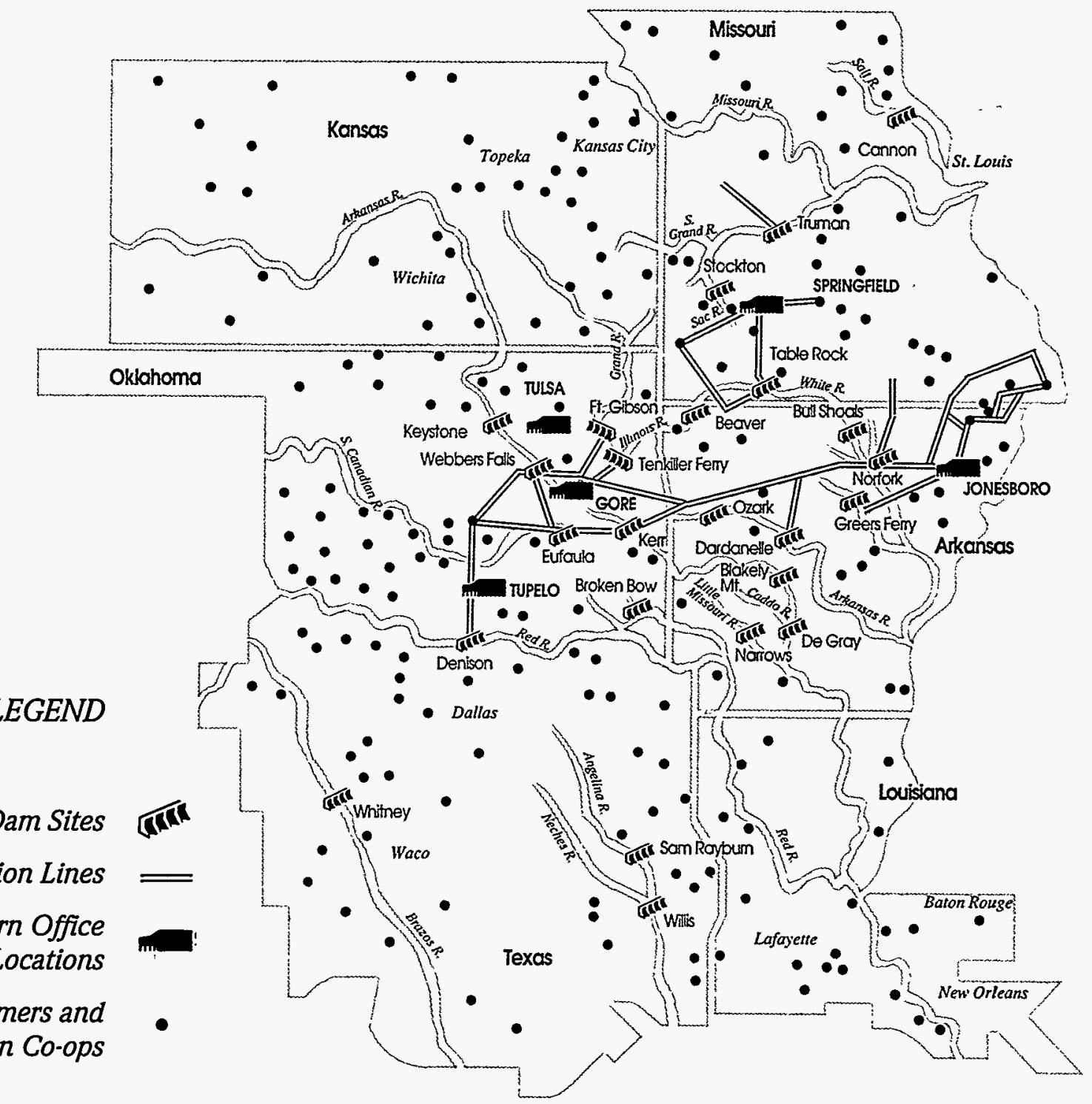




\section{OVERVIEW}

\section{Financial Statement Presentation}

1. The financial statements have been prepared to report the financial position and results of operations of the Southwestern Federal Power System pursuant to the requirements of the Chief Financial Officers Act of 1990.

2. While the statements have been prepared from the books and records of the Southwestern Power Administration and the related U.S. Army Corps of Engineers in accordance with the formats prescribed by the Office of Management and Budget, the statements are different from the financial reports used to monitor and control budgetary resources which are prepared from the same books and records.

3. The statements should be read with the realization that they are for a component of a sovereign entity, that liabilities not covered by budgetary resources cannot be liquidated without the enactment of an appropriation, and that the payment of all liabilities other than for contracts can be abrogated by the sovereign entity.

\section{Performance Measurements}

Performance measurements which are used to determine effectiveness and efficiency of programs in the areas of financial performance and program performance are:

Debt service coverage ratio

Cumulative principal payments as a percent of total Federal investment

Percent variance of actual from planned annual principal payments

Net cash flow to the Treasury

Lost work day case rate

Total recordable case rate

Motor vehicle accident rate

Transmission system performance index

Total pounds of polychlorinated biphenyl (PCB) disposed

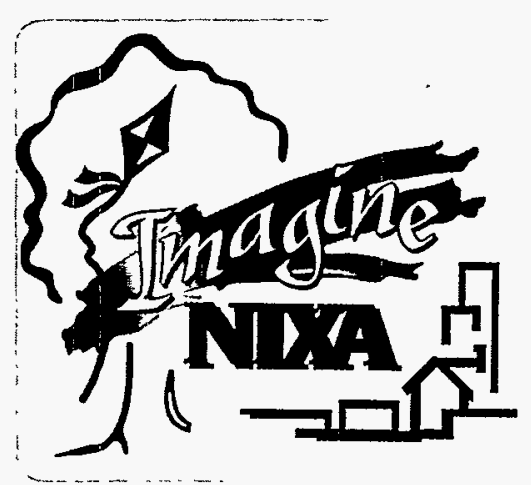

(See page 34 for detailed performance measurements.)

\section{National Performance Review}

Southwestern is developing plans in response to the National Performance Review mandate which directs specific areas of reform within the Government. Those reforms target reducing the Federal budget and increasing revenues by decreasing employment by 250,000 people, increasing employee-to-supervisor ratios, reducing service contracts by 20 percent, decreasing the number of directives and regulations by half, and increasing revenues from the Power Marketing Administrations.

Government agencies have been allowed three to five years to comply with the individual mandates. 


\section{D}

Participation, Communication Work

in Water Resource Management

\section{Southwestern Power Administration is more than an electric utility.}

Over the past decade, more and more issues have surfaced regarding the use of water resources, integrating "competing uses" with those of the "authorized uses." Available resources, a variety of unique interests ranging from trout hatcheries and boat docks to environmental considerations and agriculture, as well as evolving philosophical changes over 50-plus years, have affected today's opinions and attitudes regarding the equitable use of water resources.

"Water Resource Management" is the consolidation of these issues at Southwestern, and reflects the Agency's desire to work with other interests to use the water resources to the maximum benefit possible.

Southwestern's first priority of water resource management is to its preference power customers. Not only do they depend on the power produced, but the revenues collected from them are essential to repay the investment made by the Government for the 24 hyrdroelectric power projects in Southwestern's region. Without these revenues, all U.S. taxpayers would bear the burden of repayment.

Southwestern is mindful of both its customer and financial responsibilities. It is also aware that in today's climate of change, all wants and needs must be balanced. With that in mind, the Agency is actively involved with many groups who, although not representing "authorized" purposes, are sincere and dedicated to their various missions and publics.

\section{White River Issues Diverse}

Southwestern is actively involved in White River issues and participates on numerous committees and work groups. The Agency chaired the White River Dissolved Oxygen Committee which is composed of representatives from Arkansas and Missouri State agencies and two Federal agencies. The committee continued its progress toward the development of an operating plan that is concerned with two key issues:

1) to provide a suitable habitat for trout downstream from the dams, and

2) to permit production of power and energy at the rate for which the White River hydroelectric projects were designed.

Southwestern also serves as a member of the White River Ad Hoc Work Group. This group includes representatives of Federal and State agencies, fish and wildlife, agriculture, power and energy production, navigation, and interested parties representing upstream and downstream recreational facilities to coordinate the interests of each of these groups in the operation of power projects.

The ad hoc group worked on an interim regulation plan during the year for operation of the U. S. Army Corps of Engineers' (Corps) White River projects. The plan attempts to mitigate adverse impacts to the authorized uses of the projects while providing benefits to the many other users of these water resources. It allowed the work groups to see how a change might impact their needs without having to commit to a permanent change.

Southwestern, the Corps and State agencies in Arkansas and Missouri cooperated on a special project below Bull Shoals and Norfork dams during 1992 and 1993 to assess the affects of low dissolved oxygen (DO) on trout life cycles. 


\section{YEAR IN REVIEW}

Forty-four brown and rainbow trout were implanted with radio transmitters to track their travels and viability. The results, assessed during 1994 by the Arkansas Game and Fish Commission and the White River Dissolved Oxygen Committee, reflect several facts:

- With DO levels of six milligrams per liter (6 mg/l) or above, trout do not seek an area with higher DO;

- With the DO levels between $4-6 \mathrm{mg} / \mathrm{l}$, the trout seek other necessities for survival such as habitat, food and shelter from water velocity; and

- With the DO levels below $4 \mathrm{mg} / \mathrm{l}$, the trout seek areas of highest available DO.

The assessment also noted that during the annual spawning run, the brown trout traveled upstream as far as 25 miles within a two-day period. Post-spawn migration showed that the trout returned to within 50 -to-100 yards of the area in which they were located prior to the spawning season. Several new spawning sites were also identified during the study.

This information will be used in developing future operating plans for the Bull Shoals and Norfork hydroelectric projects. Southwestern's objective is full production of power and energy at the rates for which the projects were designed.

\section{Agencies, Other Interests Work Together}

Southwestern is also involved with State fish and wildlife agencies and local interests in the vicinity of Lake Texoma to improve waterfowl habitat. Working through the Lake Texoma Advisory Committee, Southwestern operated the Denison Dam project to facilitate planting Japanese millet to provide both food and cover for migratory ducks and geese. The Lake Texoma Advisory Committee, established by the Water Resources Act of 1986, is a group comprised of interested parties from Federal, State and local government and from a variety of other water resource interests.

Southwestern has made similar planting opportunities available around Keystone Lake in northeastern Oklahoma.

The "Black Start" project is another example of Southwestern's interaction within the region. Southwestern, the Corps of Engineers and the Southwest Power Pool have agreed to a study which would investigate the feasibility of starting specific thermal plants during a power blackout using the hydroelectric projects. It is important to ensure that thermal power plants (coal, gas-fired, or nuclear) can be re-started since they do not have the capability to start up without a sufficient source of power from the system. Hydroelectric projects can provide that source uniquely without outside help.

These are but a few of the issues, and groups, in which Southwestern participates. Ongoing communication will continue with Southwestern's partner, the Corps of Engineers, not only pertaining to water releases for generating hydroelectric power, but in regard to water resource management for navigation, agricultural and recreational needs of the public.

Moving into the 21 st century must involve committed cooperation and sincere communication. Southwestern Power Administration is a customer-focused organization, a citizen of six states, and an ambassador to the public. Balancing the Agency's mission with multi-dimensional needs is a challenge, and an opportunity for the future. 


\section{System Reliability is Major Focus}

Southwestern continues with its focus on system reliability. During FY 1994, line protection relays used to minimize damage to power system components when fault conditions occur - were replaced on 14 circuit breakers in Carthage, Table Rock, Poplar Bluff and Doniphan, Missouri and in Norfork and Water Valley, Arkansas.

Southwestern's protective relaying systems have been upgraded by replacing 67 aging relay carrier transceivers with current models or with fiberoptic communications. These transceivers allow protective relays at one terminal of a transmission line to "signal" relays at other terminals on the line. Installations were completed during the year at Carthage, Neosho, New Madrid, Springfield and Table Rock, Missouri; at Beaver, Bull Shoals, Greers Ferry, Jonesboro and Ozark, Arkansas; and at Gore and Weleetka, Oklahoma.

System-wide, other equipment upgrades and additions were completed. Six Remote Terminal Units (RTUs) were installed at Southwestern substations, four were installed at Corps of Engineers sites and one at a customer-owned substation. An RTU is an electronic device that reports information, such as when and where a circuit breaker trips, to a master computer at the Operations Center.

In addition to equipment upgrades, much of Southwestern's reliability also depends upon cleared rightsof-way and the ability to gain access to any part of its transmission system at any time. By preventing brush and tree growth from obstructing the rights-of-way, accidental connection between limbs and lines due to strong winds is reduced.

As a part of the integrated power system, utilities must work together to keep the entire system errorfree. During the year, the Southwest Power Pool, in response to a major outage that affected several systems in southwest Missouri, western Arkansas and eastern Oklahoma, strongly urged its members to take a more active role in clearing all rights-of-way.

\section{Alternate Clearing Methods Studied}

Of Southwestern's 2,220 kilometers (1,380 miles) of transmission line, approximately 1,126 kilometers (700 miles) have brush that must be cleared regularly. Currently, mechanical methods (brush hogs, chain saws, etc), which are highly labor intensive, are used in Southwestern's right-of-way clearing. Southwestern is also considering herbicide application in addition to mechanical methods. The use of herbicides is often a better alternative because

- it is more cost effective;

- herbicides eliminate dense brush while promoting the growth of desirable grasses; and

- soil erosion is reduced.

The use of herbicides would be a significant change in operation for Southwestern. To use the herbicides, the National Environmental Policy Act (NEPA) requires studies to determine effects on the environment. Southwestern is in the process of an environmental assessment to meet this requirement. Early public scoping was performed in 1994 to get input from the general public. The input received will be incorporated into the environmental assessment during FY 1995. Other State and Federal agencies within Oklahoma, Missouri and Arkansas were also notified that Southwestern is studying vegetation control methods. 
The Energy

\section{A. C. Bennett and Charles Underwood \\ Cajun Electric Power Cooperative}

A

cres and acres of pecan groves filled with stately old trees. Fields of fresh picked cotton, forgotten tufts still hanging on tight. Slow moving rivers, and easy going people. Air humid and thick with mosquitoes.

It's the deep South, specifically, Melrose Plantation just south of Natchitoches, Louisiana, the oldest settlement west of the Mississippi River. Like entering a scene from Gone With the Wind, you feel the history, the legends and the people who walked here before you. Like other ancient plantation homes that are still carefully tended in the area, Melrose epitomizes the generations who created and cultivated it along with the cotton, tobacco, corn and other crops for 200 years. Writers and artists also embody the plantation's expansive history, granting visitors the privilege of experiencing a small part of life so many years ago. Locals are proud of their heritage and are quick to point out the old family names that still survive like the moss-laden trees they live among.

The historical plantation and surrounding area are served by Valley Electric Membership Corporation based in

Natchitoches. Both A. C. Bennett and Charles Underwood (right) are board members of Cajun Electric Power Cooperative, a power supplier for Valley Electric, and a Southwestern customer. They stand under a towering 220year-old live oak tree that takes its proper position in front of "the big house" at Melrose Plantation.

Natchitoches, a charming community on the banks of the

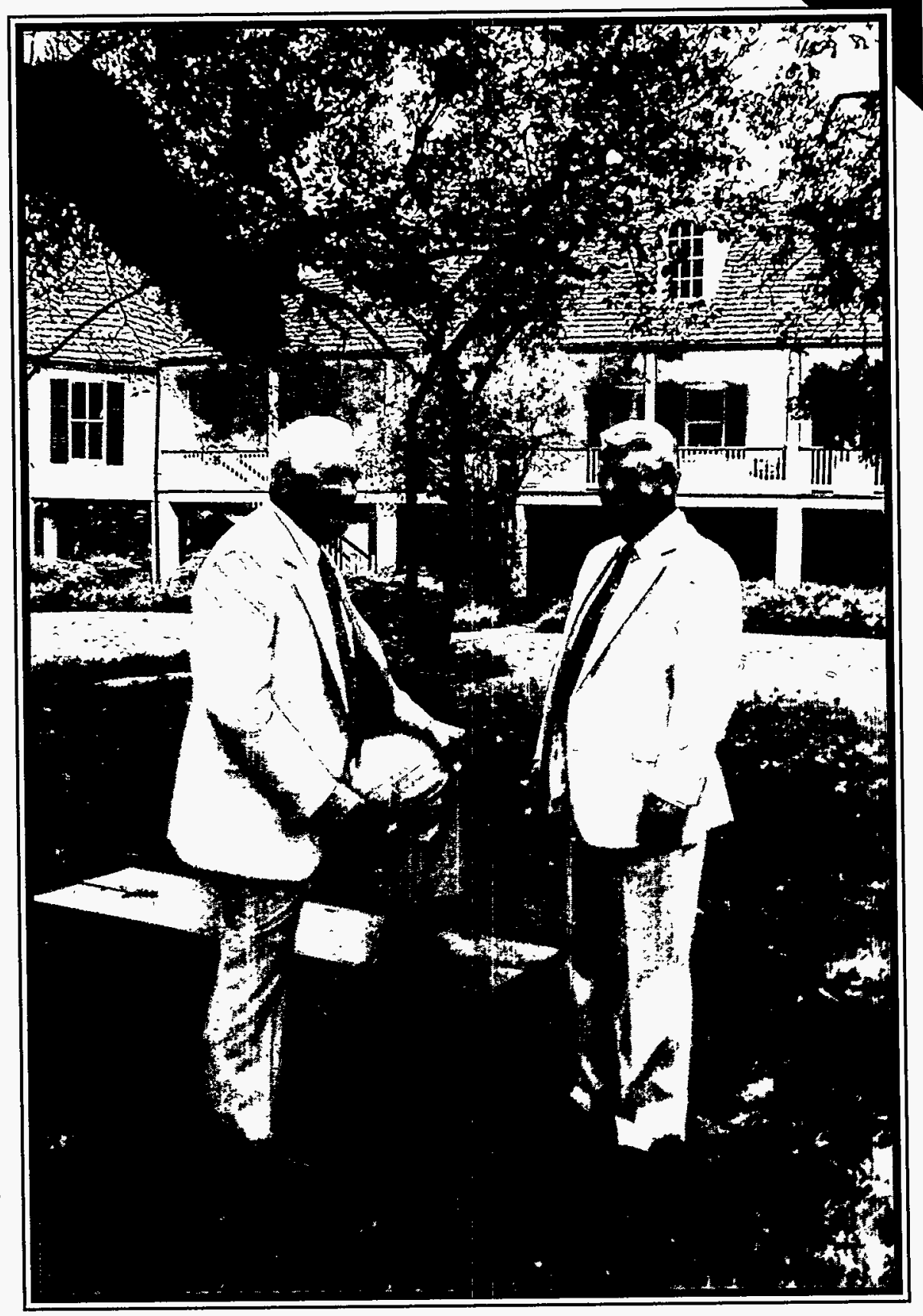
Cane River, is one of Southwestern's 78 municipal customers. It is a town rich in French history and Southern beauty that hangs heavily in a romantic period long past. 
The Energy
Bend
the power

\section{Rhonda Davis and Darrell Phillips \\ Paragould, Arkansas}

\section{$66 \mathrm{C}$}

Omall Town, America" is often overlooked in these days of interstate highways and always-in-a-hurry people.

That is a loss to many folks, because Paragould, Arkansas, is one of those towns you'd really hate to miss. Paragould is one of Southwestern's municipal customers. It's a gentle community

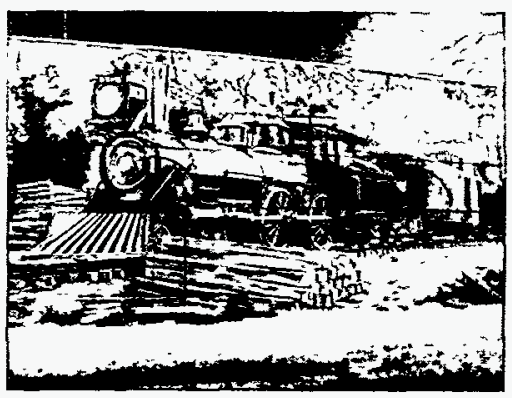
surrounded by the bottomlands known to the South. There, rice, cotton and soybeans grow in the fertile soil, and provide a good living for its citizens.

There are plenty of nice things about Paragould. For instance, the people. And two in particular are Rhonda Davis and Darrell Phillips. They share the job of Assistant General Manager

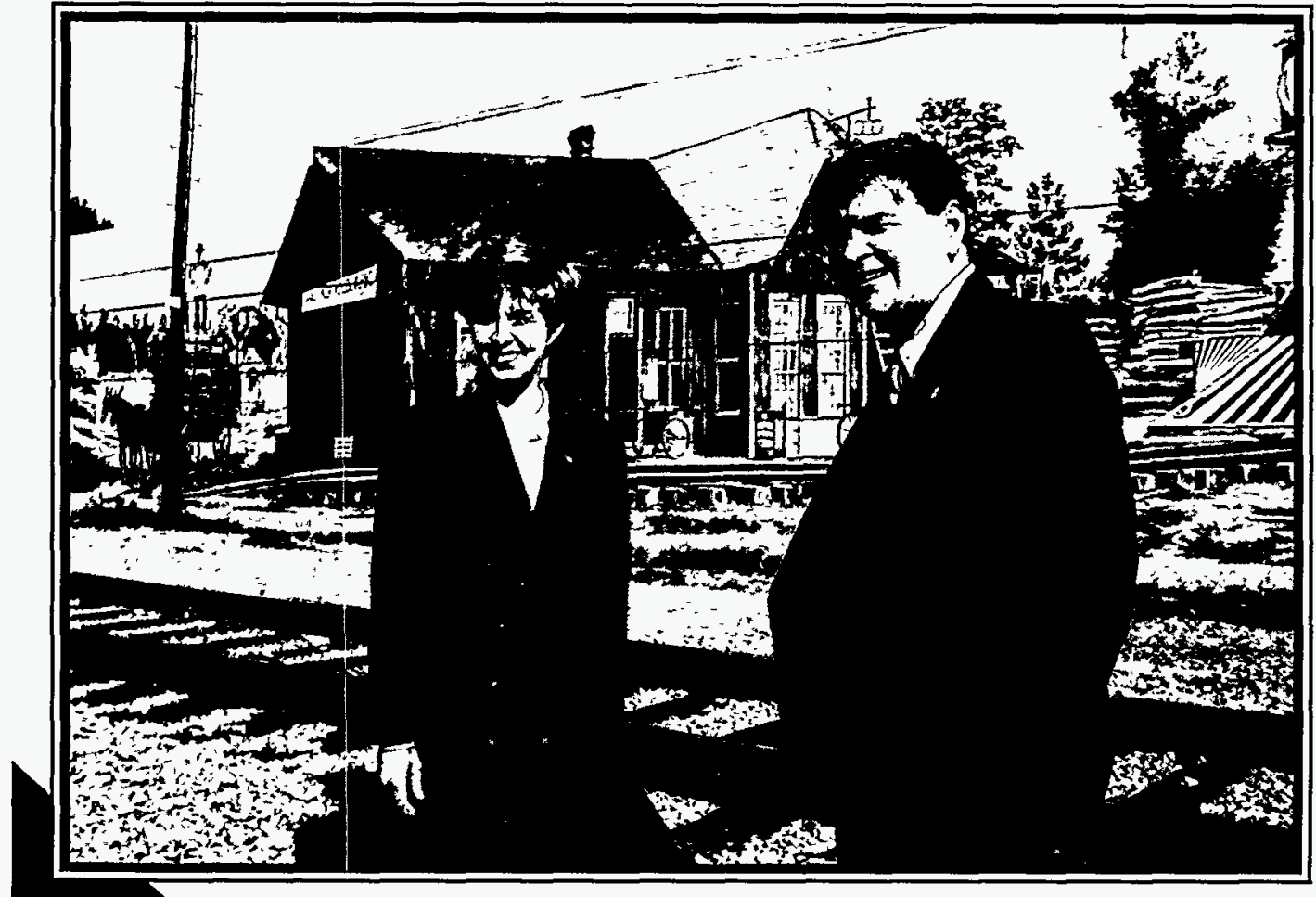
for City Light and Water. Both grew up around the town, went off to college, and came home again to raise families and work. Both swear they wouldn't have it any other way, that it's great to be a part of their hometown, to watch it grow and to help make things happen.

Another nice thing about Paragould is the "Paragould Mural." People from miles around drive over to the railroad tracks to see it for themselves. This work of art, painted on the brick that was once the outer wall of the train depot, depicts the early days of the town.

The Paragould Mural took local artist Connie Burns nearly two years to complete. It has a three-dimensional appearance with the building's actual doors and windows also painted into the scenes. The mural was created to pay tribute to the railroad, and it's easy to stand across from the tracks looking at it for long periods of time, not wanting to miss any of the story that emerges magically from the wall.

Taking a drive across the country, or just around the county? Take some extra time. There is plenty to see, and the rewards are guaranteed. 


\section{YEAR IN REVIEW}

\section{Southwestern Makes NERC "Honor Roll"}

Every control area is required to measure its generation performance. That measurement is compared to standards established by the North American Electric Reliability Council (NERC) to see if those results are acceptable. The criteria established by NERC measures how well generation is matched with load. In 1994, as in 1993 , Southwestern achieved a 96.5 percent performance index, an "honor roll" rating.

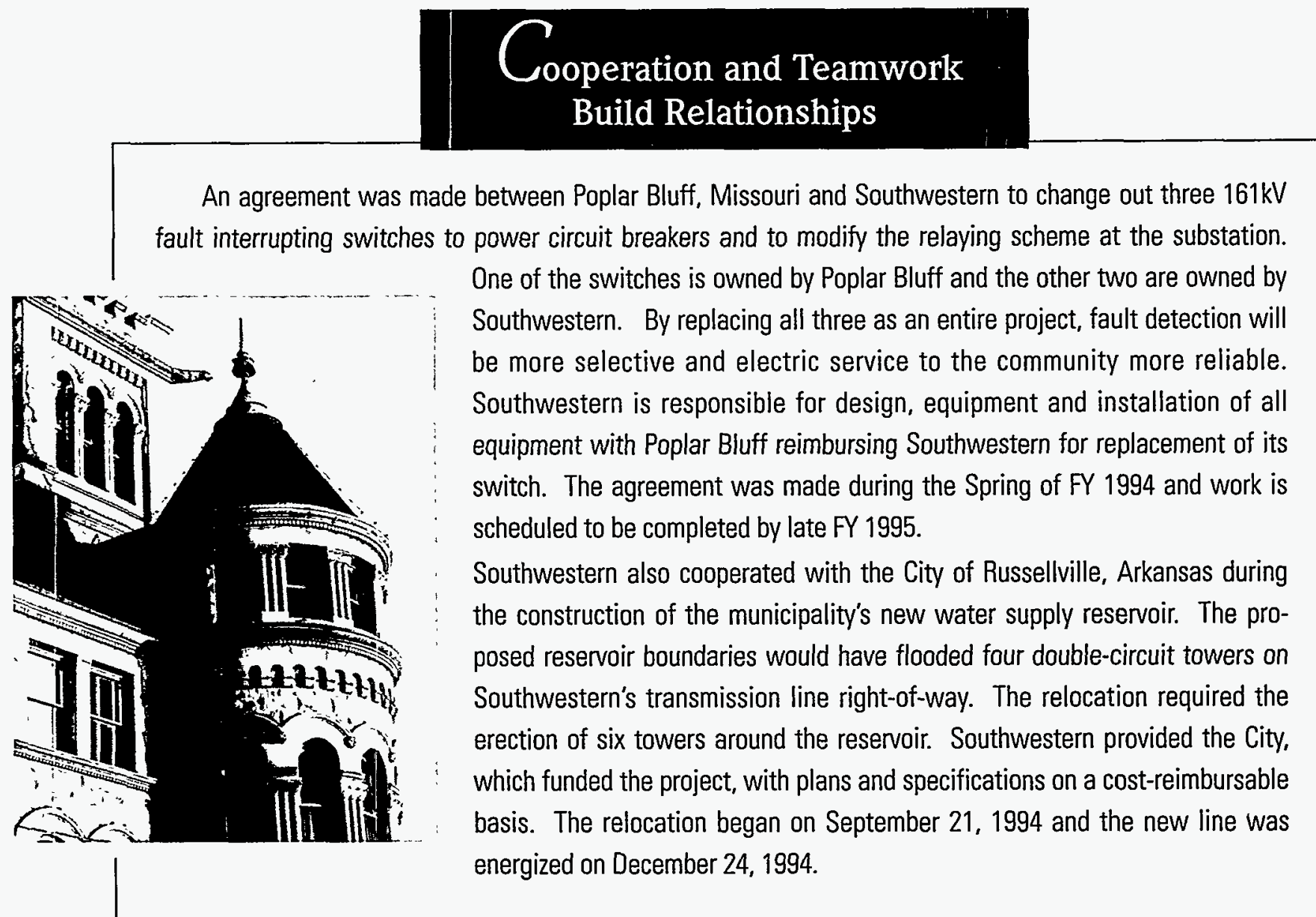

\section{Rate Increases Limited}

During 1994, two Southwestern customers received rate increases beginning October 1, 1994. Subsequently, these rates were approved by the Federal Energy Regulatory Commission (FERC) on a final basis during the first quarter of FY 1995. The increases were necessary, primarily due to Corps of Engineers revised cost estimates, to bring estimates more in line with actual expenditures.

A 3.4 percent rate increase was established for the Sam Rayburn Municipal Power Agency at the Robert D. Willis hydroelectric power project. A 4.4 percent increase was set for the Sam Rayburn Dam Electric Cooperative, Inc. at the Sam Rayburn Dam project. The new rates are effective through September 30, 1998. 
A rate change was not needed this fiscal year for Southwestern's Integrated System which includes the remaining 22 Corps of Engineers hydroelectric projects and Southwestern's transmission system. The existing rates were extended through September 30, 1995.

\section{Seeking Improvement Through Communications}

Even though Southwestern's customer base remains much the same each year, the people, issues and needs often change. With these changes in mind, Southwestern began drafting a customer survey in 1994 to be distributed in 1995. Its purpose is twofold: to determine customer expectations and to identify areas for process and service improvement.

Southwestern's Customer Service Division has made this survey a major priority. One purpose of the survey is to address the requirements of Executive Order 12862 "Setting Customer Service Standards." Southwestern will use the survey results to focus on those issues identified through the survey as important to customers. Results will be published by the end of 1995.

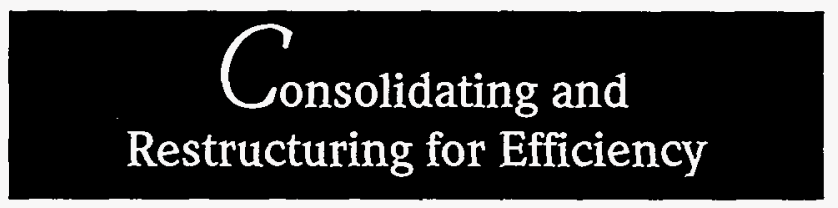

Southwestern has taken major steps to achieve its goal of flattening the organization.

The number of supervisors has been reduced and the supervisor-to-employee ratio has decreased. Completion of this initiative places Southwestern ahead of schedule to be in full compliance with the Administration's National Performance Review (NPR) which determined that all agencies should halve their ratios.

The Office of Maintenance had a significant reorganization during 1994. The Office is taking a systems approach to planning and identifying requirements for work activities and emphasis is placed on system reliability and customer requirements.

The Office of Administration and Rates reorganized and developed a Division of Information Resources Management to meet the challenge of greater efficiency. This Division will ensure Southwestern's ability to focus on both the technological requirements of the future as well as efficiency opportunities today in the areas of telecommunications and computers.

One of the Division's major accomplishments is the installation of circuits and equipment necessary to provide high-speed data transfer activities among the different Southwestern offices and facilities. Electronic mail, file and document transfer, and meeting or other activity scheduling are all now routinely handled in a more effective and timely manner.

By establishing a standard for current technology personal computers, employees are provided with resources needed to become more effective in their work. Standardization of equipment also reduces overall maintenance and support costs as well as providing a foundation to support future system implementations. 
The Energy
Bentine power

\section{Dan O'Brien}

Kaw Valley Electric Cooperative

Bud and Marti Newell Topeka, Kansas

$T$

he gates of Serenata Farms open wide and visitors are greeted like long-awaited friends.

Upon entering, senses collide with observing the operations of a modern ranch while

simultaneously feeling the history of the Old West.

For an added touch of flavor, visitors can just step out the back door of the farm offices.

There, just a short hike away, you can walk with the ghosts of pioneers along the swales of the old Oregon Trail where more than 500,000 people moved across the great plains in search of a better life.

Located just east of Topeka and across the road from Big Springs, Serenata Farms is headquarters for a number of businesses including their Oregon Trail Adventure Company. Owners Bud and Marti Newell love what they've created over the years and their enthusiasm is just as spirited for their existing projects as any new ones which are sure to come. They are unmistakably committed to their most recent goal: to provide riding lessons for disabled people of all ages with their championship Arabian horses. Their passion for their animals and the equestrian arts are the motivating factor that everyone - no matter the physical capability - should be able to experience the joy of the ranch and the Arabians.

Complemented by its devoted owners, Serenata ("a musical composition containing passages that are both exciting and tranquil") Farms, served by Kaw Valley Electric Cooperative, is no

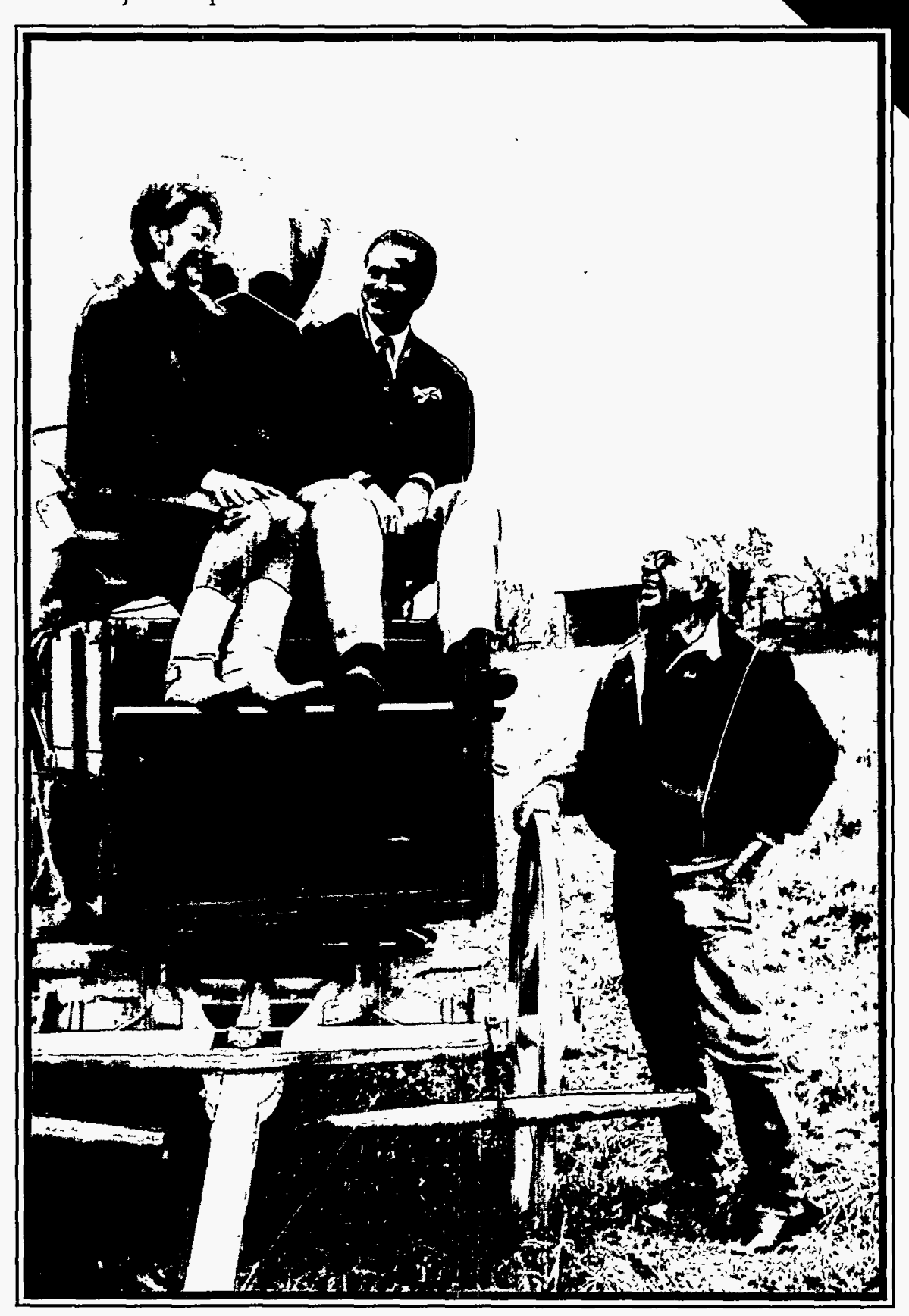
doubt a legacy of those pioneers who forged ahead on the same land with hopes, dreams and accomplishments that will blaze the trails of the future. 
The Energy
Benthe power

\section{Bruce Stephens}

City Utilities of Springfield, Missouri

\section{He} the latter 18th century, living in an era that was untamed, rugged and exciting.

Bruce Stephens, the grandson of a blacksmith, hardly misses a modern-day Rendezvous those weekend gatherings where serious "black powder" enthusiasts get together to relive the activities, dress and food of a bygone era. In the hey-day of the fur trade, rendezvous were yearly gatherings of the trappers and mountain men who came to sell their "plews" (furs) to the fur companies. In

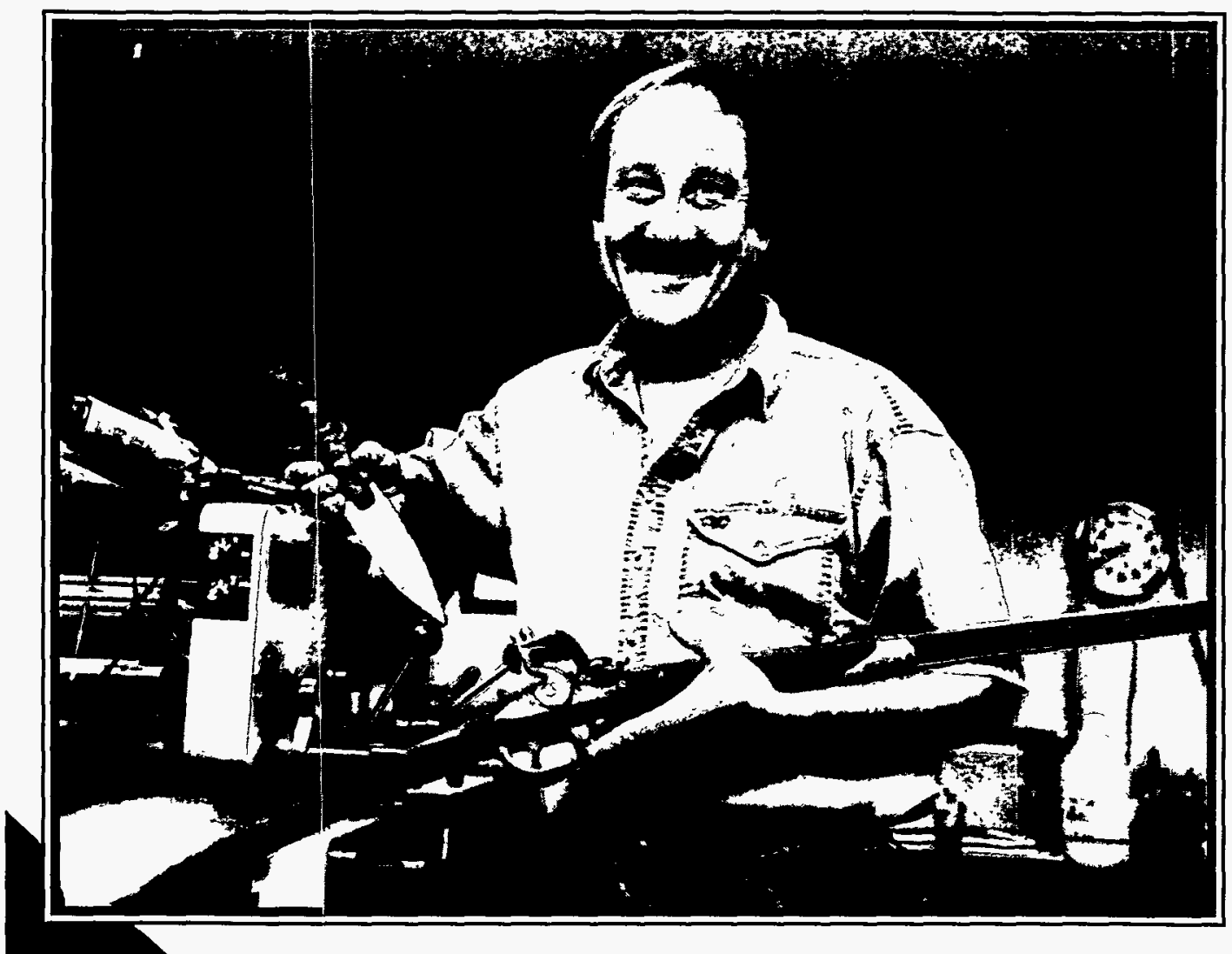
exchange for a year's worth of back-breaking work and hardship, they received a very small amount of money. That usually was spent on whiskey and the necessities of life (powder, shot, knives and trade goods). The rendezvous became an important event in the otherwise marginal lives of the trappers.

Bruce's interest in the fur trade has been kindled by research into his family's past.

Today, Bruce and his family participate together in these rendezvous outings. He sells muzzle-loading guns and other period goods to finance his excursions.

Surrounded by 21 st century technology in the print shop at City Utilities in Springfield, Missouri, Bruce seems perfectly content to spend part of his time living his hobby of the past. 


\section{YEAR IN REVIEW}

Another critical task for the new Division of Information and Resource Management is to assist in the installation of the new Supervisory Control and Data Acquisition System/Energy Management (SCADA/EMS). The SCADA/EMS will bring additional reliability and features for controlling the flow of electricity within the Southwestern system. The state-of-the-art system, scheduled for installation during FY 1995, is located within the new 2,230 square meter (24,000 square feet) Maintenance and Operations Center in Springfield. The Center makes use of energy-efficient technology and contains automated features such as movement sensors, backup power supply, and features controlled by computer such as fire and security protection, and temperature and humidity controls. Several Southwestern teams, including those from Procurement, Operations, Maintenance, Engineering and Information Resources Management, played significant roles in the research, planning, coordination and building of both the SCADA/EMS and the Operations Center

\section{$F$ ocus on Safety Targets OSHA Standard, Aviation and Security}

Informing employees and managers of the new Occupational Safety and Health Administration Standard 29 CFR 1910.137 and 1910.269 was the major safety focus during the year. Transmission, substation and electronics teams from the Office of Maintenance gathered in July, along with several representatives from Southwestern's customer groups, to participate in the workshop designed to update industry personnel on the latest OSHA regulations. The new regulations target the work practices used during the operation and maintenance of electric power generation, transmission and distribution. The OSHA standard became effective January 31, 1994.

Southwestern conducted an aviation self-assessment and was also evaluated by a Departmental "tiger team" in the aviation field. Most of their written recommendations have been implemented and positive comments have been received from other companies on Southwestern's new procedures.

Safety and health activities are also recognized in construction contracts and in procurement. Southwestern personnel are making efforts to continuously strive toward participative management and teamwork. The goal is to "think safety" and "good health" as part of the work process.

\section{Environmental Commitment Expanded}

Southwestern's commitment to an expanded environmental program is established in the Agency's revised Strategic Plan.

During 1994, Southwestern's main effort was focused on the field implementation of the 14 specific environmental programs developed during 1993. These various programs are being set in motion where field sites, with the assistance of the Office of Environment, Safety, Health and Security, can meet and maintain the standards established by the Department and the Environmental Protection Agency.

Southwestern's Security office has focused upon increasing security at all of the manned field facilities along with a review of the unmanned facility security requirements. Security plans for each manned facility are expected to be in place by the third quarter of 1995 . 


\section{Streamlining Improves Procurement Process}

Many changes are underway within Southwestern's Division of Acquisition and Property Management in coordination with the Department of Energy's efforts to reform and streamline procurement procedures.

As a member of the Department of Energy's Procurement Streamlining Team, Southwestern participated in the development of more than 200 streamlining suggestions to improve the procurement process. Sixtyfour of these suggestions were adopted by the Department for pilot programs, for waiver of regulation, or for providing new authorities to allow people to do their jobs faster and more efficiently. The Team also agreed on a set of performance measures to establish a baseline for different types of procurement contracts.

Southwestern is also a member of the Department's Pilot Program to automate the procurement and contracting function. The project was implemented in conjunction with the Western Area and Southeastern Power Administrations; with Department Headquarters Procurement Office at Oak Ridge, Tennessee; with Richland Operations Office at Richland, Washington; and with the Pittsburgh, Pennsylvania Technology Center.

Additionally, the enactment of the Federal Acquisition Streamlining Act made significant improvements in small purchase acquisitions, in the contract administration area, and in the formulation of contracts.

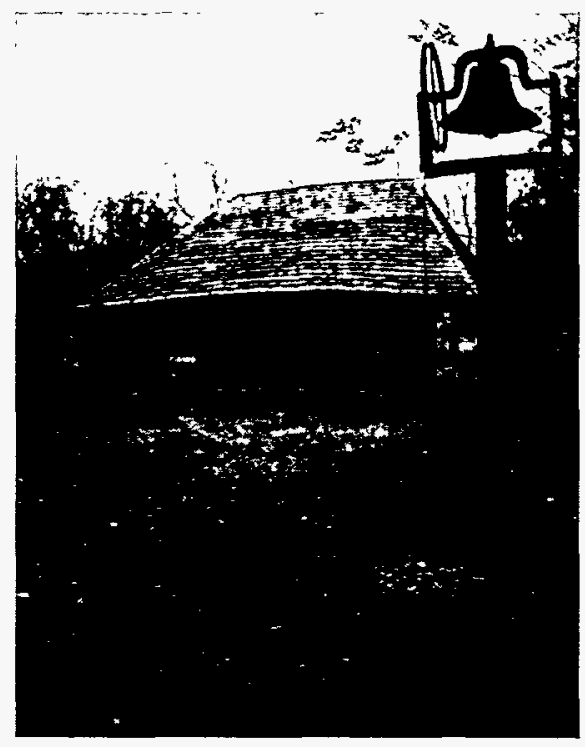

\section{Benefits Multiply with Financial Management Advances}

Several labor-and time-savings programs were implemented during 1994 by Southwestern's Financial Management Division. These programs provide faster service for both internal and external customers and enable the Agency to pass savings on to customers through lower administrative costs, ultimately reflected in Southwestern's rates.

- The Electronic Certification System (ECS) is an automated system for voucher preparation, certification, transmission and verification. ECS significantly reduces the cost of each payment from 36 cents per check to six cents per Automated Clearing House transfer. 


\section{Juan Nichols and Joe Brady}

Wood County Electric Cooperative and

Northeast Texas Electric Cooperative

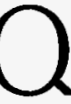

uitman, Texas is the home of Wood County Electric Cooperative and is famous for being the hometown of academy award winning actress Sissy Spacek. But to serious bass fishermen, it's most famous as "The Big Bass Capital of Texas."

Two Quitman natives who are among the disciples of the acclaimed Lake Fork and its prize catches are Juan Nichols and Joe Brady.

Juan (pictured right) is the General Manager and Executive Vice President of Wood County Electric and the President of Tex-La Electric Cooperative. He is also a charter board member of the Northeast Texas Electric Cooperative (NTEC), one of Southwestern's largest customers, and has been secretary/ treasurer since its inception. Juan's electric cooperative background is so expansive that throughout his 33-year career, he has worked with each one of Southwestern's administrators.

Joe (at left) is the Member Services Manager for Wood County. Admittedly, his true love is bass fishing, and he's fortunate enough to "moonlight" as a private guide for fishermen and women determined to go out and "catch the big ones."

The acclaimed Lake Fork, known for its 19-pound, prize-winning catches year after year, has 30,000 surface acres. That's enough water - and bass - to keep Juan, Joe and thousands of other NTEC customers satisfied for some time.
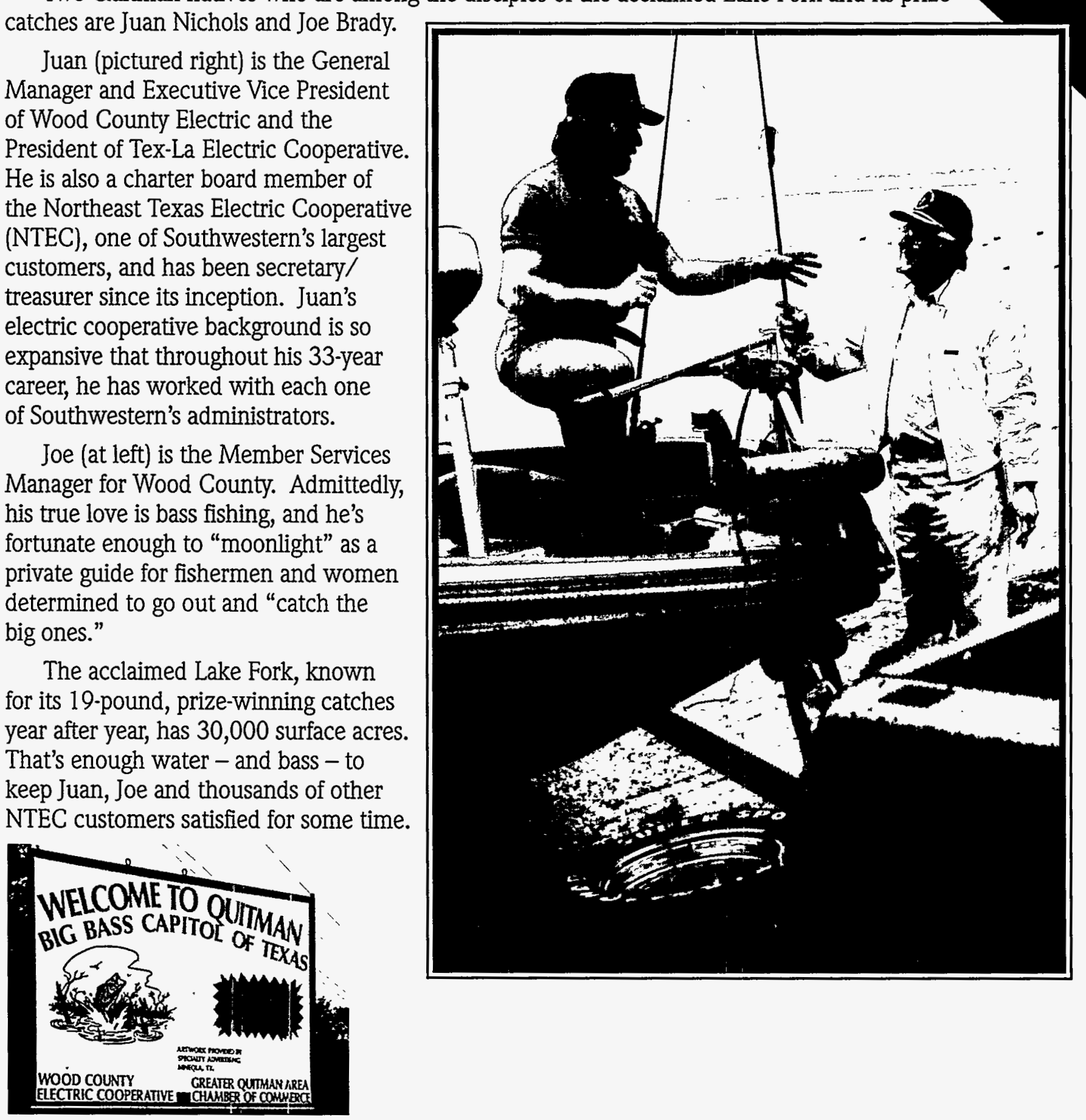
SOUTHWESTERN FEDERAL POWER SYSTEM

Combined Financial Statements and Supplemental Schedules

(With Independent Auditors' Reports Thereon)

For the Years Ended September 30, 1994 and 1993 


\author{
700 Oklahoma Tower \\ Oklahoma City, OK 73102-5671 \\ 1600 One Williams Center \\ Tulsa, OK 74172-0168
}

\title{
INDEPENDENT AUDITORS' REPORT
}

The Administrator of

Southwestern Power Administration

U.S. Department of Energy:

We have audited the accompanying combined statement of assets, Federal investment, and liabilities of the Southwestern Federal Power System (SWFPS) as of September 30, 1994, and the related combined statements of revenues, expenses, and accumulated net revenues, and cash flows for the year then ended. These combined financial statements are the responsibility of SWFPS' management. Our responsibility is to express an opinion on these combined financial statements based on our audit. The combined financial statements and supplementary combining information of SWFPS as of September 30,1993, were audited by other auditors whose report dated December 17, 1993, expressed an unqualified opinion with an explanatory paragraph that described the tentative allocation of certain utility plant costs and expenses between power and non-power purposes discussed in Note 3 to the combined financial statements.

We conducted our audit in accordance with generally accepted auditing standards; Government Auditing Standards (1988 Revision), issued by the Comptroller General of the United States; and Office of Management and Budget (OMB) Bulletin 93-06, Audit Requirements for Federal Financial Statements. Those standards require that we plan and perform the audit to obtain reasonable assurance about whether the financial statements are free of material misstatement. An audit includes examining, on a test basis, evidence supporting the amounts and disclosures in the financial statements. An audit also includes assessing the accounting principles used and significant estimates made by management, as well as evaluating the overall financial statement presentation. We believe that our audit provides a reasonable basis for our opinion.

In our opinion, the combined financial statements referred to above present fairly, in all material respects, the financial position of the SWFPS as of September 30,1994, and the results of its operations and changes in accumulated net revenues and its cash flows for the year then ended in conformity with generally accepted accounting principles.

Our audit was made for the purpose of forming an opinion on the combined financial statements taken as a whole. The combining information as of and for the year ended September 30, 1994, is presented for purposes of additional analysis of the combined financial statements rather than to present the financial position, results of operations and changes in accumulated net revenues and cash flows of the two groups of accounts as described in Note 1 . The combining information has been subjected to the auditing procedures applied in the audit of the SWFPS financial statements and, in our opinion, is fairly stated in all material respects in relation to the 1994 financial statements taken as a whole. 
As discussed in Note 3 to the combined financial statements, certain utility plant costs and operation and maintenance expenses relating to multi-purpose projects have been allocated on a tentative basis between power and non-power purposes. The amount of adjustments, if any, that may be necessary when the final allocations are made are not presently determinable. Accordingly, no adjustments to the related assets, revenue and expense accounts have been recognized in the accompanying combined financial statements.

As discussed in Note 6 to the combined financial statements, there is an uncertainty related to the amount of interest on Federal investment that is required to be recognized. The ultimate outcome of the matter cannot presently be determined. Accordingly, no provision for any liability that may result from the resolution has been recognized in the accompanying combined financial statements.

Our audit was made for the purpose of forming an opinion on the combined financial statements taken as a whole. The information presented in management's Overview and Performance Measurements is not a required part of the financial statements, but is supplementary information required by $\mathrm{OMB}$ Bulletin 94-01, Form and Content of Financial Statements. We have considered whether this information is materially inconsistent with the combined financial statements. Such information has not been subjected to the auditing procedures applied in the audit of the combined financial statements and, accordingly, we do not express an opinion on it. The performance information included in management's Overview and Performance Measurements is addressed in our auditors' report on internal control structure in accordance with OMB Bulletin No. 93-06.

KP II Peat Mannish REP

Tulsa, Oklahoma

December 16, 1994

19 


\section{SOUTHWESTERN FEDERAL POWER SYSTEM}

\section{Combined Statements of Assets, Federal Investment, and Liabilities September 30, 1994 and 1993}

\section{Assets}

Utility plant:

Plant in service

Accumulated depreciation

Construction work in progress

Retirement work in progress

Net utility plant

Current assets:

Unexpended appropriations

Accounts receivable

Materials and supplies, at average cost

Banking exchange

Other assets

\section{Federal Investment and Liabilities}

Federal investment:

Investment of U.S. Government:

Congressional appropriations

Transfers from other federal agencies

Interest on Federal investment

Funds returned to U.S. Treasury

Net investment of U.S. Government

Accumulated net revenues

Total Federal investment

Current liabilities - accounts payable and accrued liabilities

Purchase power and banking exchange deferral

Hydropower revenue deferral

Commitments and contingencies (Notes 3 and 5)

Total Federal investment and liabilities
1994

1993

$$
\begin{array}{r}
\$ 1,037,732,999 \\
(262,106,439) \\
33,892,080 \\
94,123 \\
\hline 809,612,763 \\
\hline
\end{array}
$$

$1,025,621,415$

$(250,539,198)$

$22,124,448$

104,431

$797,311,096$

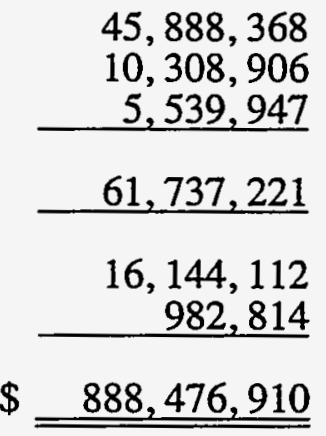

$38,975,438$

$10,439,719$

$3,925,819$

$53,340,976$

$15,579,585$

650,817

$866,882,474$

$$
\begin{array}{rr}
\$ 1,924,187,761 & 1,844,397,199 \\
26,723,735 & 26,204,747 \\
619,894,268 & 601,461,624 \\
(1,797,143,072) & (1,697,636,459 \\
\hline 773,662,692 & 774,427,111 \\
67,782,348 & 47,144,736 \\
\hline 841,445,040 & 821,571,847
\end{array}
$$

$11,121,248$

$35,608,965$

301,657

$9,278,886$

$35,747,376$

284,365

$\$ \quad 888,476,910$

$866,882,474$

The accompanying notes are an integral part of these power system combined financial statements. 


\section{SOUTHWESTERN FEDERAL POWER SYSTEM \\ Combined Statements of Revenues, Expenses, and Accumulated Net Revenues \\ Years ended September 30, 1994 and 1993}

\section{Revenues: \\ Sales of electric power: \\ Cooperatives \\ Municipalities \\ Federal and state agencies \\ Investor owned utilities \\ Banking exchange \\ Transmission service charges for others \\ Other \\ Total revenues before deferrals}

Net purchase power credit and banking exchange

Total revenues

Expenses:

Operation and maintenance

Purchase power and banking exchange

Depreciation

Transmission service charges by others

Other

Total expenses excluding interest

Net revenues before interest expense

Interest expense on Federal investment

Allowance for funds used during construction

Net revenues

Accumulated net revenues:

Balance at beginning of year

Balance at end of year
1994

1993

$$
\$
$$

$$
\begin{array}{r}
66,795,409 \\
27,054,771 \\
4,347,196 \\
1,300 \\
6,381,237 \\
3,015,334 \\
306,513 \\
\hline 107,901,760
\end{array}
$$

$70,873,303$

$25,736,676$

$3,758,622$

49,166

$8,705,049$

$2,796,419$

286,328

$112,205,563$

$\begin{array}{ll}1,501,755 & 3,542,538 \\ 109,403,515 & 115,748,101\end{array}$

$\underline{109,403,515}$

$\underline{115,748,101}$
$43,331,000$

$6,474,934$

$10,872,345$

$2,690,554$

$(36,218)$

$\underline{63,332,615}$

$52,415,486$

$38,734,750$

\begin{tabular}{|c|c|}
\hline $47,144,736$ & $11,989,586$ \\
\hline $67,782,348$ & $47,144,73$ \\
\hline
\end{tabular}

$19,750,066$

$(1,652,928)$

$18,097,138$

$18,253,338$

$(993,002)$

$17,260,336$

$20,637,612$

$35,155,150$

The accompanying notes are an integral part of these power system combined financial statements. 


\section{SOUTHWESTERN FEDERAL POWER SYSTEM \\ Combined Statements of Cash Flows \\ Years ended September 30, 1994 and 1993}

Cash provided by operating activities:
Net revenues
Items not requiring cash:
Interest expense on Federal investment
Depreciation
(Increase) decrease in:
Accounts receivable
Materials and supplies
Banking exchange
Other assets
Increase (decrease) in:
Accounts payable and accrued liabilities
Purchase power and banking exchange deferral
Hydropower revenue deferral

Cash provided by operating activities

Cash used in investing activities:

Additions to utility plant $\underline{1994}$

1993

$\$ 20,637,612$

$18,097,138$
$12,634,514$

130,813

$(1,614,128)$

$(564,527)$

$(331,997)$

$1,842,362$

$(138,411)$

17,292

$\underline{50,710,668}$

$(22,764,265)$

$(1,652,928)$

$(17,352,640)$

$(993,002)$

$(24,417,193)$

$(18,345,642)$
$35,155,150$

$17,260,336$

$10,872,345$

205,059

$(13,127)$

$(3,550,205)$

$(209,442)$

763,741

$(1,811,377)$

13,143

$58,685,623$

Cash used in investing activities

$(101,431,850)$

$53,718,887$

Funds returned to U.S. Treasury

Congressional appropriations

Interest on Federal investment - purchase power deferral

$(99,506,613)$

$79,790,562$

$(751,993)$

Cash used in capital financing activities

$(\underline{19,380,545)}$

$(48,464,956)$

Net increase (decrease) in cash

$6,912,930$

$(8,124,975)$

$\underline{38,975,438}$

$47,100,413$

Cash at beginning of year

$\$ \underline{\underline{45,888,368}}$

$\underline{38,975,438}$

Cash at end of year

Noncash investing activities and other transactions -

Transfer of plant in service from other Federal agencies

$\$ \lcm{518,988}$

107,408

The accompanying notes are an integral part of these power system combined financial statements. 


\section{SOUTHWESTERN FEDERAL POWER SYSTEM \\ Notes to Financial Statements \\ September 30, 1994 and 1993}

\section{(1) Summary of Significant Accounting Policies}

General Information and Basis of Preparation of Financial Statements

The accompanying financial statements of the Southwestern Federal Power System include the accounts of the Southwestern Power Administration (Southwestern), a unit of the U.S. Department of Energy (DOE), and the accounts of the Southwestern hydroelectric generating plants and power operations of the U.S. Army Corps of Engineers (Corps), a unit of the Department of Defense. These two groups of accounts are collectively referred to as the "Southwestern Federal Power System" (SWFPS).

The Corps has constructed and operates hydroelectric generating plants in the states of Oklahoma, Missouri, Arkansas and Texas. Costs of multi-purpose Corps projects are allocated to power and non-power purposes. The portion of such project costs allocated to power is included in the financial statements. Southwestern, as designated by the Secretary of the DOE, purchases, transmits and markets power.

Southwestern and the Corps are separately managed and financed and each maintains its own accounting records. For purposes of financial and operational reporting, the facilities and related operations are considered one entity. SWFPS' income and facilities are exempt from taxation.

SWFPS is subject to the regulations of the Federal Energy Regulatory Commission (FERC). Accounts are maintained in accordance with generally accepted accounting principles, the uniform system of accounts prescribed for electric utilities by the FERC, the accounting practices and standards established by the DOE, and the requirements of specific legislation and executive directives issued by government agencies. SWFPS' financial statements are prepared in accor dance with Statement of Financial Accounting Standards No. 71, Accounting for the Effects of Certain Types of Regulation (SFAS No. 71), which requires that the effects of the rate-making process be recorded. Such effects can provide reasonable assurance about the existence of an asset, reduce or eliminate the value of an asset, or impose a liability on a regulated enterprise.

Utility Plant and Depreciation

Plant in service and construction and retirement work in progress consist principally of generating and transmission facilities as follows:

\begin{tabular}{|c|c|c|}
\hline \multirow{3}{*}{$\begin{array}{l}\text { Generating facilities } \\
\text { Transmission facilities }\end{array}$} & 1994 & 1993 \\
\hline & $\begin{array}{r}\$ 926,360,391 \\
145,358,811 \\
\end{array}$ & $\begin{array}{l}916,641,572 \\
131,208,722\end{array}$ \\
\hline & $\$ 1,071,719,202$ & $1,047,850,294$ \\
\hline
\end{tabular}

Plant in service and construction and retirement work in progress are stated at original cost or at appraisal value for property transferred from other government agencies. Cost includes direct labor and materials, payments to contractors, indirect charges for engineering, supervision and similar overhead items, and allowance for funds used during construction. The costs of additions and betterments are capitalized. Repairs and minor replacements are charged to operation and maintenance expense. Generally, the cost of utility plant retired, together with removal costs less salvage, is charged to accumulated depreciation when it is removed from service. Gains and losses are recognized only on sales of significant identifiable assets.

Depreciation on utility plant is computed on a straight-line basis over the estimated service lives of the various classes of property. Service lives are currently estimated to average approximately 41 years for transmission plant and 93 years for generating plant. Upon review of utility plant facilities usage, it was determined that depreciation formally charged to power production should be charged to other purposes. Accordingly, a one-time $\$ 1,700,000$ reduction of depreciation was recorded in 1993. This change will not have a material impact on future periods.

Unexpended Appropriations

Unexpended appropriations consist of the unexpended balance of funds appropriated by Congress for construction and operation and maintenance purposes and are maintained by the U.S. Treasury. For purposes of the statements of cash flows, unexpended appropriations are considered to be cash.

Congressional Appropriations

Congressional appropriations received by the Corps are authorized and allocated to individual projects on a total project basis. These total project allocations are further distributed among power and non-power purposes at the discretion of project management. Power purpose allocations may vary from actual amounts expended during the year. It is the intent of Corps project management to distribute congressional appropriations in amounts approximating estimated current year expenses and to adjust the distribution as necessary within the limits of the transfer authority residing at the district level.

\section{Revenues}

Operating revenues are recorded on the basis of service rendered. Rates are established under requirements of the Flood Control Act of 1944, related legislation and executive departmental directives, and are to provide sufficient revenues to meet all required payments for system costs, including operation and maintenance expenses less depreciation expenses including interest and payment to the U.S. Treasury for the Federal investment in utility plant. Rates are intended to provide for recovery of the Federal investment in transmission and generating facilities within the service lives of the assets, not to exceed 50 years 


\section{SOUTHWESTERN FEDERAL POWER SYSTEM \\ Notes to Financial Statements \\ Continued}

from the date placed in service, while operation and maintenance costs and interest on Federal investment are recovered annually.

As set forth in "Utility Plant and Depreciation" above, assets are being depreciated for financial reporting purposes using the straight-line method over their estimated service lives which currently average approximately 41 years for transmission facilities and 93 years for generating facilities. Accordingly, annual depreciation charges are not matched with the recovery of the related capital costs and will, in the case of generating facilities, continue beyond the period within which such costs will have been recovered through rates.

While energy and transmission rates are established to recover the costs of operating the power projects, rates are also required to be at the lowest possible level, consistent with sound business principles. Over the life of the power system, accumulated net revenues represent differences between the timing of the recognition of expenses and related revenues, resulting primarily from the difference between the recognition of depreciation and the related recovery of the U.S. Treasury's investment in utility plant. SWFPS is a nonprofit agency, thus at any given time the accumulated net revenue (deficit) balance is deemed to represent deferred revenue or expense, respectively.

The practice followed by SWFPS is in conformity with the accounting practices and standards established by the DOE and the requirements of specific legislation and executive directives issued by government agencies.

Purchase Power and Banking Exchange Deferral

A separate rate component (adder) recovers the cost of purchased power based upon the average purchased power costs over the past several years. If the actual expenses of purchased power exceed the revenue generated from this adder, the cost is deferred for future recovery through rates. Likewise, if the expense is less than the adder, the excess revenue is deferred. In 1988 , SWFPS determined that the deferred revenue accumulated from the adder exceeded estimated requirements. As a result, refunds of the adder have been accomplished by including a purchase power credit in the rate schedules approved for the period July 1, 1988 through September 30, 1994. SWFPS calculates interest on the purchased power deferral at the applicable current interest rate established in the fiscal year of the deferral. Such interest is deferred to offset future purchase power costs.

SWFPS has arrangements with certain customers in which excess power generated by SWFPS is banked with the customer until needed by SWFPS and the customer has excess power available. SWFPS records a receivable for the power banked at the customers' cost of generation. The net revenue or expense associ- ated with banking activity is deferred.

\section{Interest on Federal Investment}

Interest on Federal investment is a cost mandated by the Secretaries of the Departments of Energy and Defense and the FERC. Southwestern computes interest in accordance with DOE Order RA 6120.2 which provides that interest be computed on the remaining investment after revenues have been applied to recovery of costs during the year, any prior year unpaid costs, and then to Federal investment, bearing the highest interest rate first (see Note 4).

Allowance for Funds Used During Construction (AFUDC)

The FERC Uniform System of Accounts defines AFUDC as the net costs for the period of construction of borrowed funds used for construction purposes and a reasonable rate on other funds when so used. While cash is not realized currently from this allowance, it is realized under the rate making process over the repayment life of the related property through increased revenues resulting from higher recoverable investment. The interest rates used are established by law, administrative order or administrative policy for the fiscal year during which the construction commenced (Fiscal Year 19947.125 percent).

\section{Retirement Benefits}

All employees engaged in SWFPS activities participate in either the Civil Service Retirement System (CSRS) or the Federal Employees' Retirement System (FERS). Both are contributory defined benefit pension plans. Retirement benefit expense under CSRS is equivalent to seven percent of eligible employee compensation and under FERS is variable based upon options chosen by the participants but does not exceed 24.2 percent of eligible employee compensation. Actuarial data regarding funding is not available. Retirement benefits are payable by the U.S. Government and not by SWFPS. In addition, certain health care benefits are provided for substantially all retired employees. The cost of providing these benefits is an expense of the U.S. Government and not SWFPS.

\section{(2) Confirmation and Approval of New Rates}

Integrated system rate schedules were confirmed and approved by the FERC on a final basis on September 18,1991 . These rates were placed into effect on a two-step incrementally increasing basis for the period October 1, 1990 through September 30, 1994. The final increase of 5.7 percent became effective April 1, 1992. On August 29, 1994, the rates were extended through September 30, 1995, by the Deputy Secretary of Energy. The Sam Rayburn and Robert Douglas Willis projects are presently under rates which were confirmed and approved by FERC on a final basis on August 11, 1993, and are in effect from 


\section{SOUTHWESTERN FEDERAL POWER SYSTEM \\ Notes to Financial Statements \\ Continued}

October 1, 1993 through September 30, 1997. The Sam Rayburn project experienced a 14.7 percent increase in rates while the Robert Douglas Willis project experienced a 30.4 percent decrease in rates.

(3) Tentative Cost Allocations

Allocations of plant cost and operation and maintenance expense between power and non-power purposes for four of the Corps' operating projects are presently based on tentative allocations. At September 30, 1994 , total plant costs for these four projects were $\$ 1,176,020,691$, of which $\$ 310,813,886$ was tentatively allocated to power and subject to adjustment. The amount of adjustments that may be necessary when final allocations are approved for these projects is not presently determinable. When final allocations are made, the cumulative effect will be determined and reflected as an adjustment to the financial statements at that time.

The Harry S. Truman project has a tentative cost allocation of $\$ 155,637,527$. Since being placed in service, this project's operations have been restricted. The restrictions have prevented the project from producing power to its design capacity. A final determination of when, if ever, the project can reach full generating capacity has not yet been made. If the restriction on generating capacity is not removed, some change in allocation of cost may be required. If such a change in allocation is required, the cumulative effect will be determined and reflected as an adjustment to the financial statements at that time.

\section{(4) Investment of U.S. Government}

Construction and operation of the SWFPS transmission system and the Corps' generating plants and operations are financed through Congressional appropriations, except for the Robert Douglas Willis project which is financed by other parties. The U.S. Government investment in each generating project and each year's investment in the transmission system is to be repaid to the U.S. Treasury within the service lives of the assets, not to exceed 50 years from the time the facility is placed in service. There is no requirement for repayment of a specific amount on an annual basis. Annual revenues are first applied to the current year operating expenses (less depreciation) and interest expense. All annual amounts for such expenses have been paid through fiscal year 1994. Remaining revenues are to be first applied to repayment of operating deficits (which include all expenses except depreciation), if any, and then to repayment of the Federal investment. To the extent possible, while still complying with the repayment period established for each increment of investment and unless otherwise required by legislation, repayment of the investment is to be accomplished by repayment of the highest interest-bearing investment first. Interest rates applied to the unamortized initial investment of U.S. Government in the Corps' hydroelectric plants range from 2.5 percent to 3.125 percent for facilities in service at the beginning of the year and 7.125 percent for facilities placed in service during 1994. Interest rates applied to the unamortized investment of U.S. Government in Southwestern transmission facilities are approximately 2.5 percent for facilities in service at the beginning of the year and 7.125 percent for facilities placed in service during 1994. The rates have been set either by law, by administrative order pursuant to law, or by administrative policies using the U.S. Senate Document No. 97 formula for the fiscal year during which the appropriations were requested.

(5) Commitments and Contingencies

Based on the 1994 Integrated System Power Repayment Study, the projected increase in capital investment in 1995 is $\$ 19,713,885$ which includes $\$ 5,843,900$ for transmission facilities and $\$ 13,869,985$ for generating facilities. The five-year investment increase projected in the 1994 Power Repayment Study for 1995 through 1999 is estimated to cost $\$ 95,742,534$.

SWFPS is a party to certain claims and legal actions arising in the ordinary course of business. In addition, the Corps has begun studies for the purpose of determining whether possible environmental contamination exists at various dam locations. The cost of remediation, if any, at these sites is unknown. In management's opinion, these actions will not have a material adverse effect on the financial condition or results of operations of SWFPS.

(6) Restatement of Federal Investment

It was not determined how to properly recognize interest on Federal investment for power assets placed into service by the Corps districts within SWFPS between 1970 and 1988. Interior Department Order 2929 was issued in 1970 and generally requires the use of annual interest rates as set by the U.S. Treasury Department for new power projects. The Corps and the DOE agreed in 1983 to begin using the U.S. Treasury interest rate in the calculation of the interest on the Federal investment related to new power projects. The agreement also stipulated that the interest rates from 1970 to 1983 be analyzed to insure compliance with the agreement. No Corps district had implemented the U.S. Treasury interest rate provisions prior to fiscal year 1989.

The DOE and the Corps are currently researching the correct interest computation. As of December 16, 1994, no resolution of this matter has occurred. As such, no additional interest on Federal investment for the period 1970 to 1994 has been included in the accompanying financial statements. Resolution of this matter may require additional interest on Federal investment to be recognized. 


\section{SOUTHWESTERN FEDERAL POWER SYSTEM}

\section{Combining Statements of Assets, Federal Investment, and Liabilities}

September 30, 1994

\section{Assefs}

Utility plant:

Plant in service

Accumulated depreciation

Construction work in progress

Retirement work in progress

Net utility plant

\section{Current assets: \\ Unexpended appropriations \\ Accounts receivable \\ Materials and supplies, at average cost}

Banking exchange

Other assets
Southwestern

\$ $120,109,786$

$(29,439,979)$

$25,154,902$

94,123

$\underline{115,918,832}$

$32,999,214$

$10,272,363$

$5,539,947$

$48,811,524$

$16,144,112$

10,493

$\$ 180,884,961$
Corns

$$
\begin{aligned}
& 917,623,213 \\
& (232,666,460)
\end{aligned}
$$

$693,693,931$

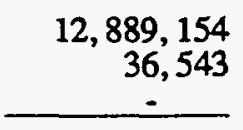

$12,925,697$

$97 \dot{2}, 321$

$707,591,949$
Total

$$
\begin{array}{r}
1,037,732,999 \\
(262,106,439) \\
33,892,080 \\
94,123 \\
\hline 809,612,763 \\
\hline
\end{array}
$$

$$
\begin{array}{r}
45,888,368 \\
10,308,906 \\
5,539,947 \\
\hline
\end{array}
$$

$61,737,221$

$16,144,112$

982,814

$888,476,910$

\section{Eederal Investment and Jiabilities}

Federal investment:

Investment of U.S. Government: Congressional appropriations

Transfers from other federal agencies Interest on Federal investment Funds retumed to U.S. Treasury Net investment of U.S. Government Accumulated net revenues (deficit)

Total Federal investment

$\$ 568,068,452$

Current liabilities - accounts payable and accrued liabilities

Purchase power and banking exchange deferral Hydropower revenue deferral

Total Federal investment and liabilities
$14,574,521$

$34,528,451$

$(549,989,294)$

$67,182,130$

$71,021,891$

$138,204,021$

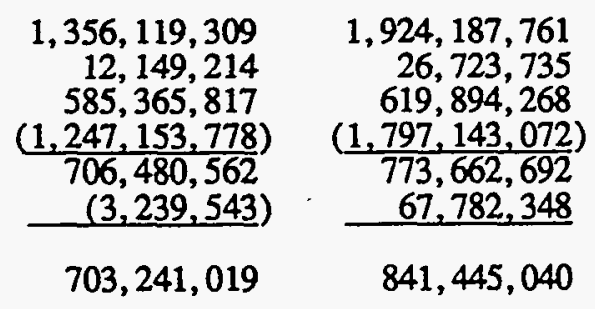

$6,770,318$

$35,608,965$

301,657

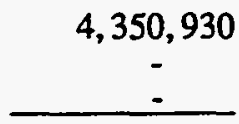

$11,121,248$

$35,608,965$

301,657

$\$ 180,884,961$ 


\section{SOUTHWESTERN FEDERAL POWER SYSTEM}

\section{Combining Statements of Assets, Federal Investment, and Liabilities}

September 30, 1993

Utility plant:

Plant in service

Accumulated depreciation

Construction work in progress

Retirement work in progress

Net utility plant

Current assets:

Unexpended appropriations

Accounts receivable

Materials and supplies, at average cost

Banking exchange

Other assets

\section{Eederal Investment and Liabilities}

Federal investment:

Investment of U.S. Government:

Congressional appropriations

Transfers from other federal agencies

Interest on Federal investment

Funds returned to U. S. Treasury

Net investment of U.S. Government

Accumulated net revenues (deficit)

Total Federal investment

Current liabilities - accounts payable and accrued liabilities

Purchase power and banking exchange deferral Hydropower revenue deferral

Total Federal investment and liabilities
Southrestern

$\$ 112,486,666$

$(26,858,571)$

$18,617,625$

104,431

$104,350,151$

$30,931,781$

$10,410,485$

$3,925,819$

$45,268,085$

$15,579,585$

$-$

$\$ \underline{\underline{165,197,821}}$
Coros

$913,134,749$

$(223,680,627)$

$3,506,823$

$692,960,945$

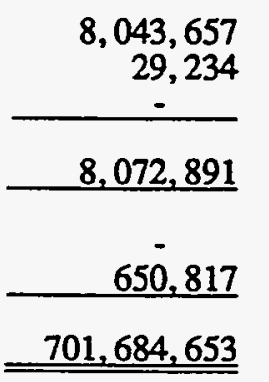

Total

$1,025,621,415$

$(250,539,198)$

$22,124,448$

104,431

$797,311,096$

$38,975,438$

$10,439,719$

$3,925,819$

$53,340,976$

$15,579,585$

650,817

$866,882,474$

$$
\begin{array}{r}
\$ 534,481,453 \\
14,576,993 \\
33,738,173 \\
(518,090,939) \\
64,705,680 \\
58,140,320 \\
\hline 122,846,000
\end{array}
$$

$6,320,080$

$35,747,376$

284,365

$\$ \underline{\underline{165,197,821}}$
$1,309,915,746$

$11,627,754$

$567,723,451$

$(1,179,545,520)$

$709,721,431$

$(10,995,584)$

$698,725,847$

$1,844,397,199$

$26,204,747$

$601,461,624$

$(1,697,636,459)$

$774,427,111$

$47,144,736$

$821,571,847$

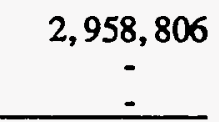

$9,278,886$

$35,747,376$

284,365

$701,684,653$

$866,882,474$ 


\section{SOUTHWESTERN FEDERAL POWER SYSTEM}

\section{Combining Statements of Revenues, Expenses,}

and Accumulated Net Revenues

Year ended September 30, 1994

\section{Revenues: \\ Sales of electric power: \\ Cooperatives \\ Municipalities \\ Federal and state agencies \\ Investor owned utilities \\ Banking exchange \\ Transmission service charges for others \\ Other \\ Total revenues before deferrals}

Net purchase power credit and banking exchange

Revenue distributed to Corps

Total revenues

\section{Expenses:}

Operation and maintenance

Purchase power and banking exchange

Depreciation

Transmission service charges by others
Total expenses excluding interest

Net revenues before interest expense

Interest expense on Federal investment

Allowance for funds used during construction

Net revenues

Accumulated net revenues (deficits):

Balance at beginning of year

Balance at end of year
Southwestern Coros Total

\begin{tabular}{rcr}
$\$ 66,795,409$ & - & $66,795,409$ \\
$27,054,771$ & - & $27,054,771$ \\
$4,347,196$ & - & $4,347,196$ \\
1,300 & - & 1,300 \\
$6,381,237$ & - & $6,381,237$ \\
$3,015,334$ & 220,459 & $3,015,334$ \\
86,054 & $\frac{306,513}{107,901,760}$ \\
\hline $107,681,301$ & 220,459 & $1,501,755$ \\
$1,501,755$ & - & - \\
$(66,600,549)$ & $66,600,549$ & \\
\hline $42,582,507$ & $\underline{66,821,008}$ & $\underline{109,403,515}$ \\
\hline
\end{tabular}

$15,870,616$

$7,751,565$

$2,932,757$

$2,645,019$

$-$

$31,786,960$

$9,701,757$

$(19,909)$

$47,657,576$

$7,751,565$

$12,634,514$

$2,645,019$

$(19,909)$

$29,199,957$

$41,468,808$

$70,668,765$

$13,382,550$

$25,352,200$

$38,734,750$

$2,153,907$

$(1,652,928)$

500,979

$17,596,159$

$\frac{-}{17,596,159}$

$19,750,066$

$(1,652,928)$

$18,097,138$

$12,881,571$

$7,756,041$

$20,637,612$

$58,140,320$

$(10,995,584)$

$47,144,736$

$\$ \underline{71,021,891}$

$(3,239,543)$

$67,782,348$ 


\section{SOUTHWESTERN FEDERAL POWER SYSTEM}

Combining Statements of Revenues, Expenses, and Accumulated Net Revenues

Year ended September 30, 1993

Revenues:

Sales of electric power:

Cooperatives

Municipalities

Federal and state agencies

Investor owned utilities

Banking exchange

Transmission service charges for others

Other

Total revenues before deferrals

Net purchase power credit and banking exchangé

Revenue distributed to Corps

Transmission service charges by others

Other

Total expenses excluding interest

Net revenues before interest expense

Interest expense on Federal investment

Allowance for funds used during construction

Net revenues

Accumulated net revenues (deficits):

Balance at beginning of year

Balance at end of year
Southwestern Coros Total

$\$ 70,873,303$

$25,736,676$

$3,758,622$

49,166

$8,705,049$

$2,796,419$

85,680

$\overline{112,004,915}$

$3,542,538$

$(81,347,399)$

$34,200,054$

$16,179,765$

$6,474,934$

$2,775,920$

$2,690,554$

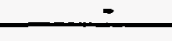

$28,121,173$

$6,078,881$

$1,604,188$

$(993,002)$

611,186

$5,467,695$

$52,672,625$

$(40,683,039)$

$\$ 58,140,320$
$11,989,586$

$\underline{(10,995,584)}$

$70,873,303$

$25,736,676$

$3,758,622$

49,166

$8,705,049$

$2,796,419$

200,648

200,648

$112,205,563$

$3,542,538$

$\underline{81,347,399}$

$81,548,047$

$115,748,101$

$27,151,235$

$8,096,425$

$(36,218)$

$35,211,442$

$46,336,605$

$43,331,000$

$6,474,934$

$10,872,345$

$2,690,554$

$(36,218)$

$63,332,615$

$52,415,486$

$18,253,338$

(993,002)

$\underline{16,649,150}$

$17,260,336$

$35,155,150$

$47,144,736$ 


\section{SOUTHWESTERN FEDERAL POWER SYSTEM}

\section{Combining Statements of Cash Flows}

Year ended September 30, 1994

Cash provided by operating activities:

Net revenues

Items not requiring cash:

Revenue distributed to Corps

Interest expense on Federal investment

Depreciation

(Increase) decrease in:

Accounts receivable

Materials and supplies

Banking exchange

Other assets

Increase (decrease) in:

Accounts payable and accrued liabilities

Purchase power and banking exchange deferral

Hydropower revenue deferral

Cash provided by (used in) operating activities

Southwestern

Corps

Total

\section{$\$$}

\begin{tabular}{rcr}
$12,881,571$ & $7,756,041$ & $20,637,612$ \\
$66,600,549$ & $(66,600,549)$ & - \\
500,979 & $17,596,159$ & $18,097,138$ \\
$2,932,757$ & $9,701,757$ & $12,634,514$ \\
$\begin{array}{c}138,122 \\
(1,614,128) \\
(564,527) \\
(10,493)\end{array}$ & $\begin{array}{c}(7,309) \\
(321,504)\end{array}$ & $\begin{array}{r}130,813 \\
(564,527) \\
(331,997)\end{array}$ \\
$\begin{array}{c}450,238 \\
(138,411) \\
17,292\end{array}$ & $1,392,124$ & $\begin{array}{r}1,842,362 \\
(138,411) \\
17,292\end{array}$ \\
\hline$\underline{81,193,949}$ & $(\underline{30,483,281)}$ & $\underline{50,710,668}$ \\
\hline
\end{tabular}

Cash used in investing activities:

Additions to utility plant

$(12,850,982)$

$(9,913,283) \quad(22,764,265)$

Allowance for funds used during construction

$(1,652,928)$

- $\quad(1,652,928)$

Cash used in investing activities

$(\underline{14,503,910}$

$(9,913,283)$

$\underline{(24,417,193})$

Cash provided by (used in) capital financing activities:

Funds returned to U.S. Treasury

Congressional appropriations

Interest on Federal investment - purchase power deferral

\begin{tabular}{|c|c|c|}
\hline $\begin{array}{c}(98,498,904) \\
33,586,999\end{array}$ & $\begin{array}{l}(1,007,709) \\
46,203,563\end{array}$ & $\begin{array}{c}(99,506,613) \\
79,790,562\end{array}$ \\
\hline 289,299 & 46,207 & 335,506 \\
\hline$(64,622,606)$ & $45,242,061$ & $(19,380,545)$ \\
\hline $2,067,4$ & $4,845,497$ & 930 \\
\hline $30,931,7$ & $8,043,657$ & $\underline{38,975,438}$ \\
\hline & $12,889,1$ & $45,888,36$ \\
\hline
\end{tabular}

Cash provided by (used in) capital financing activities

Net increase in cash

Cash at beginning of year

$\$ 32,999,214$

$45,888,368$

Noncash investing activities and other transactions Transfer of plant in service (to) from other Federal agencies

$\$$

$(2,472)$

521,460

518,988 


\section{SOUTHWESTERN FEDERAL POWER SYSTEM}

\section{Combining Statements of Cash Flows}

Year ended September 30, 1993

Southwestern Corps Total

Cash provided by operating activities:

Net revenues

Items not requiring cash:

Revenue distributed to Corps

Interest expense on Federal investment

Depreciation

(Increase) decrease in:

Accounts receivable

Materials and supplies

Banking exchange

Other assets

Increase (decrease) in:

Accounts payable and accrued liabilities

Purchase power and banking exchange deferral

Hydropower revenue deferral

Cash provided by (used in) operating activities

Cash used in investing activities:

Additions to utility plant

Allowance for funds used during construction

Cash used in investing activities

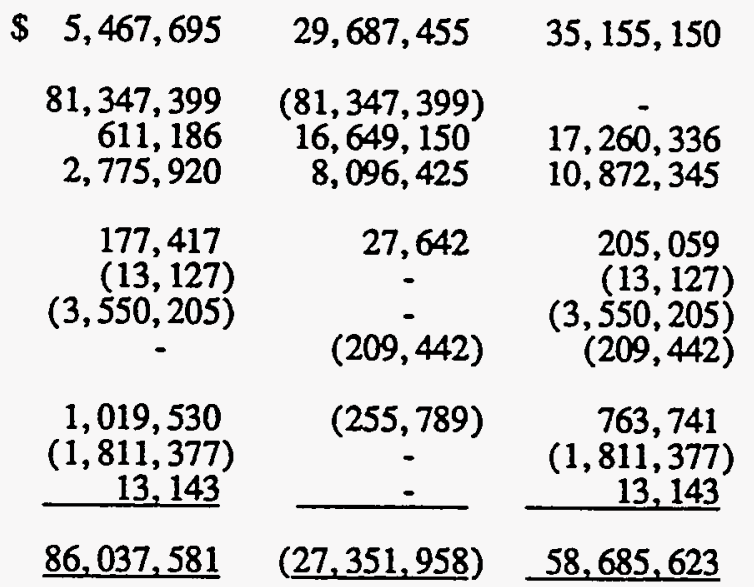

$\begin{array}{rrr}(13,935,439) & (3,417,201) & (17,352,640) \\ (993,002) & (993,002)\end{array}$

$(14,928,441) \quad(3,417,201) \quad(18,345,642)$

Cash provided by (used in) capital financing activities:

Funds returned to U.S. Treasury

Congressional appropriations

Interest on Federal investment - purchase power deferral

Cash provided by (used in) capital financing activities

Net increase (decrease) in cash

Cash at beginning of year

Cash at end of year

Noncash investing activities and other transactions -

Transfer of plant in service (to) from other

Federal agencies
$(100,623,733)$

$21,907,000$

$(738,935)$

$(808,117) \quad(101,431,850)$

$31,811,887 \quad 53,718,887$

$(13,058)$

$(751,993)$

$(79,455,668)$

$\underline{30,990,712}$

$(48,464,956)$

$(8,346,528)$

221,553

$(8,124,975)$

$\underline{39,278,309}$

$7,822,104$

$47,100,413$

$\$ \underline{\underline{30,931,781}}$

$\underline{8,043,657}$

$38,975,438$

$\$$

$(28,534) \quad 135,942 \quad 107,408$


32 
The Energy

\section{Jim Pendergrass \\ Western Farmers Electric Cooperative}

$T_{\text {nes }}$

here are 37 recognized Indian tribes in Oklahoma, the state with the largest Indian population in the Nation. And seven of those tribes - Apache, Delaware, Caddo, Commanche, Wichita, Kiowa and Ft. Sill Apache - have established their headquarters in Anadarko.

Anadarko is also the home of Western Farmers Electric Cooperative, which serves 20 customers - 19 distribution co-ops and Altus Air Force Base - and approximately 460,000 end-users throughout southern and western Oklahoma. Western Farmers, led by former

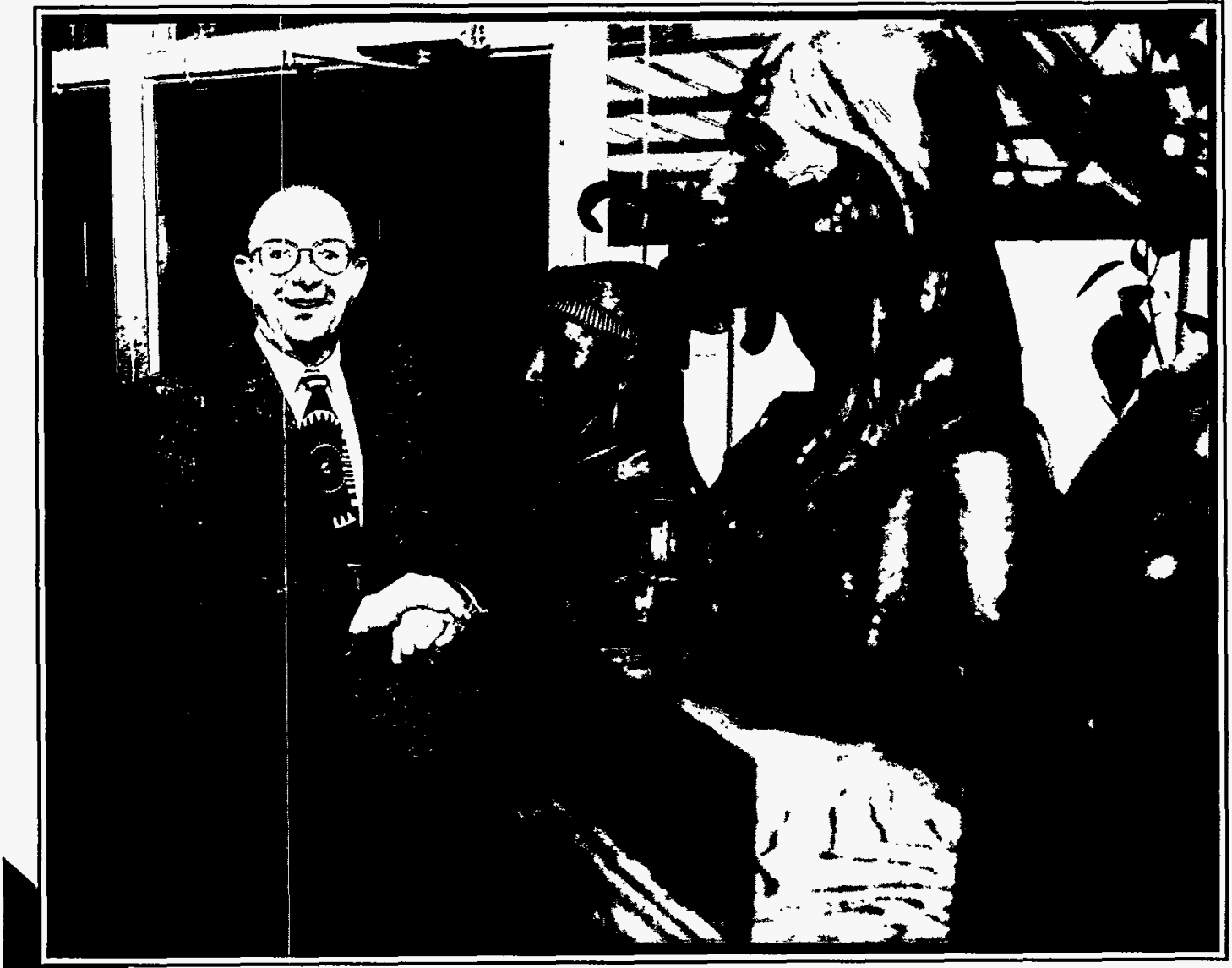

Southwestern employee Jim Pendergrass, is Southwestern's second largest customer.

Anadarko is in the heart of Indian country in Oklahoma. This community of 6,500 is known for its Indian population, and for preserving the history of the tribes and individuals who first called this country "home." Several historical museums and an Indian school are located in the area. "Indian City, USA" is an authentic restoration of American Indian dwellings. The National Hall of Fame for Famous American Indians includes a one-half-mile walk of statuary gardens with dozens of largerthan-life bronze busts. Also nearby are art galleries and Native American expositions, a wildlife refuge and state parks.

Western Farmers is a good neighbor with a great future, and it is fortunate to call Anadarko, a community that is rich in history, its home. 


\section{YEAR IN REVIEW}

Benefits Multiply with Financial Management Advances - Continued from page 15

- Vendor Express, an effective way to comply with the Prompt Payment Act, is a method of electronic payment (direct deposit) for businesses that provide goods and services to Southwestern. Streamlined operations reduce manual payment processing, payments are easily traceable and vendors benefit from the prompt availability of funds.

- Direct Deposit of Federal employee travel payments, in addition to salaries, are made into personal checking or savings accounts. Direct Deposit is an effective system for tracking salary payments.

- Optical Scanning (Imaging) is a pilot program at Southwestern for records management. Documents are scanned onto a laser disc and information is retrieved onto a personal computer screen. The system significantly reduces search time for invoices and other financial documentation.

- The Travel Manager Program is in a test phase. The program allows Agency personnel to prepare travel authorizations and travel vouchers on their personal computers. When fully integrated, it will allow electronic certification for more rapid processing of travel documents.

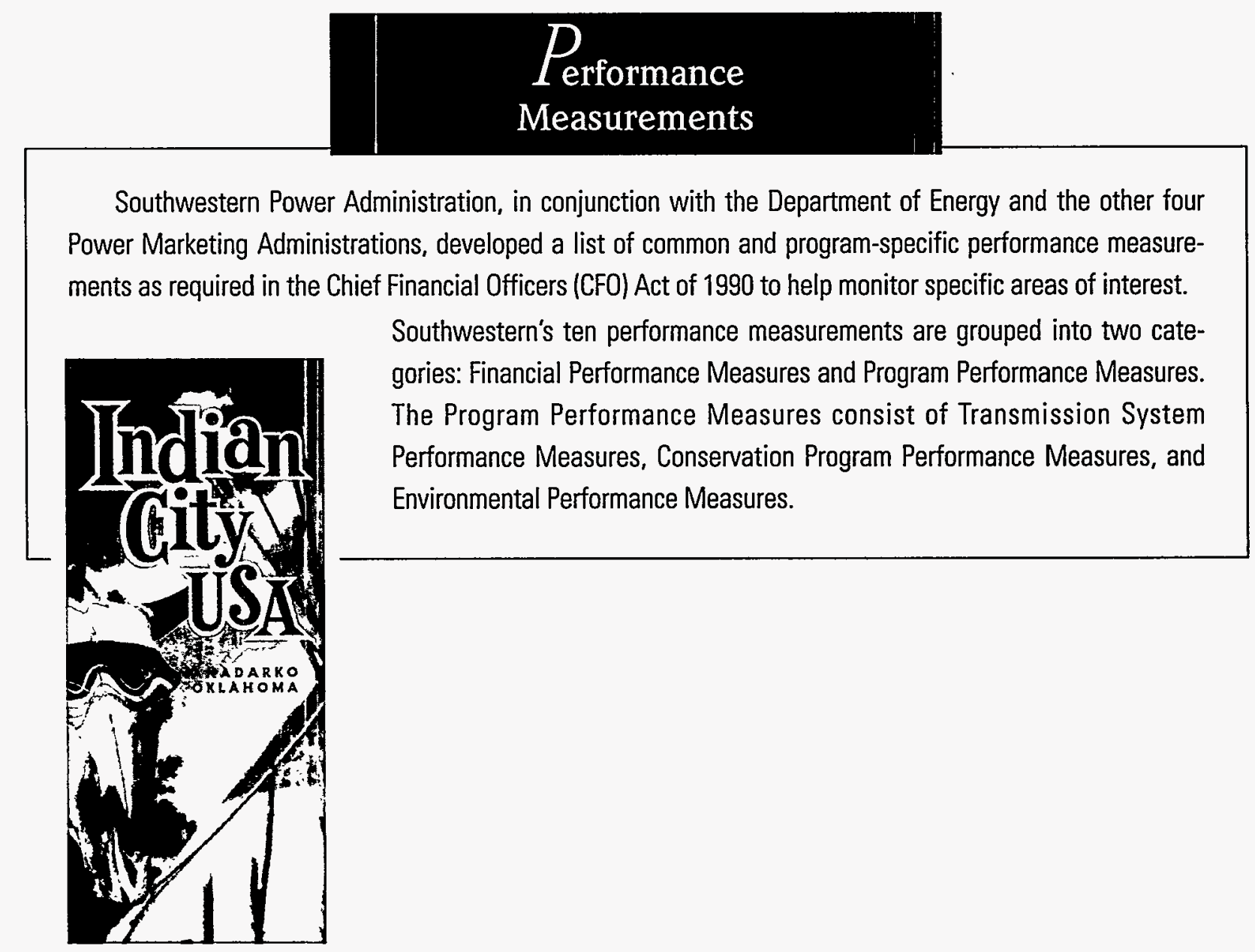




\section{Financial Performance Measures}

Southwestern has developed four financial performance measures for the past eight years. These measures, used as management tools, include the Debt Service Coverage Ratio, Cumulative Principal Payments as a Percent of Total Federal Investment, Percent Variance of Actual from Planned Annual Principal Payments, and Net Cash Flow to the Treasury. The past five years' summarization of these measures is as follows:

\begin{tabular}{lcrrrr} 
& \multicolumn{5}{c}{ Fiscal Year } \\
& 1990 & 1991 & 1992 & 1993 & 1994 \\
\hline $\begin{array}{l}\text { 1. Debt service coverage ratio } \\
\text { 2. Cumulative principal payments as a percent } \\
\quad \text { of total Federal investment }\end{array}$ & 1.495 & 1.124 & 1.142 & 1.490 & 1.265 \\
$\begin{array}{l}\text { 3. Percent variance of actual from planned } \\
\text { annual principal payments }\end{array}$ & $21.14 \%$ & $22.84 \%$ & $25.36 \%$ & $29.86 \%$ & $32.74 \%$ \\
$\begin{array}{l}\text { 4. Net cash flow to the Treasury (000's) } \\
\text { N. }\end{array}$ & $\$ 25.74 \%$ & $(8.90 \%)$ & $13.08 \%$ & $66.16 \%$ & $35.98 \%$ \\
& $\$ 17,504$ & $\$ 32,324$ & $\$ 38,162$ & $\$ 25,579$
\end{tabular}

\section{Debt service coverage ratio}

Southwestern shares a statutory and administrative requirement to establish rates that repay the U.S. Treasury for the Federal investment of its hydroelectric power systems. Rates are designed under average water conditions to provide for a 1.0 or higher debt service coverage ratio. Generally, this ratio is recognized as a direct measure of the sufficiency of cash flows to cover planned payments of both principal and interest to the U.S. Treasury.

Five-year Analysis: Southwestern's debt service coverage ratio for the past five years has exceeded the 1.0 target, indicating that annual revenues were sufficient to service the agency's planned payments.

\section{Cumulative principal payments as a percent of total Federal investment}

This measure provides information showing the relationship between the cumulative amount of principal Southwestern has repaid to date and the total Federal investment to be repaid. While analysis of this indicator does not necessarily provide conclusive information without further analysis of additional factors such as the average age of the system, relative interest rates, and other contractual commitments, the

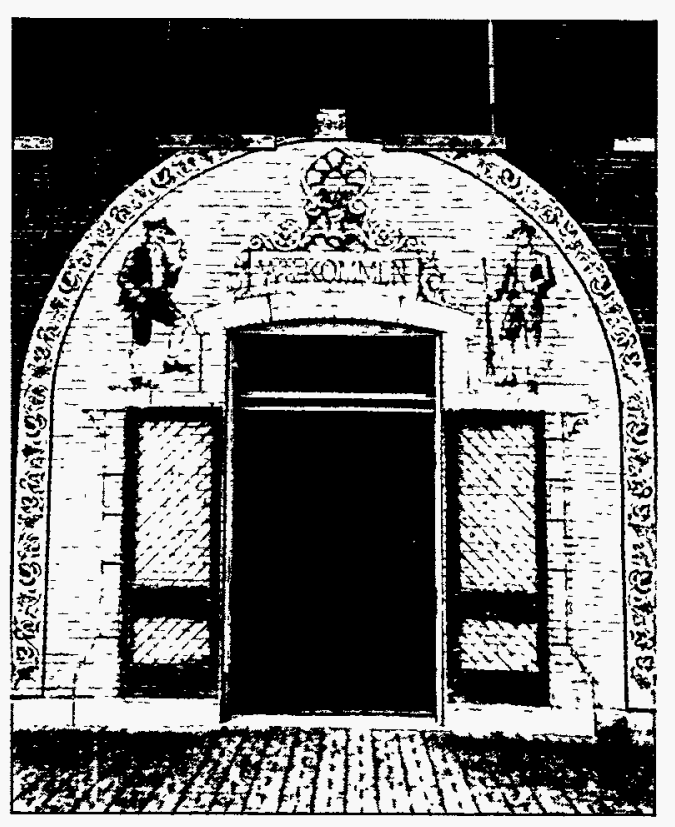
measure nevertheless provides information on the status of repayment.

Five-year Analysis: The measure illustrates that Southwestern has made continual progress toward the repayment of its total investment. 
The Energy
Bende
the power

Gerald EImore

West Plains, Missouri

$\mathrm{W}_{\mathrm{es}}$

U.S.A." by author Norman Crompton.

Gerald Elmore isn't at all surprised at the favorable designation. He grew up in and around West Plains and has worked there his entire life. He's the City Administrator and has held his current position for the last six years. He also served a term as mayor between 1980 - 1984.

His town also has the distinction of being Southwestern's oldest municipal customer with the first contract executed on November 20, 1947. Since that date, the progressive farming community has grown to a population of nearly 10,000 people and 3,000 industrial jobs.

The town boasts several unique sights. In the West Plains City Offices, which were once owned by a rural electric cooperative, inlaid wood, parquet floors, and a walnut fireplace from an old 1800s home are a part of the decor. And near the campus of the West Plains branch of Southwest Missouri State University (SMSU) stands the Kellett home, built in 1904 by a member of the first board of SMSU, M. B. Clarke. Students proudly use the home, which was donated to the university, for classes, meetings and special events.

The newest pride of West Plains is the Civic Center where people gather daily for school sporting events, and drama and art events. It is a modern community gathering place, and like the older, regal

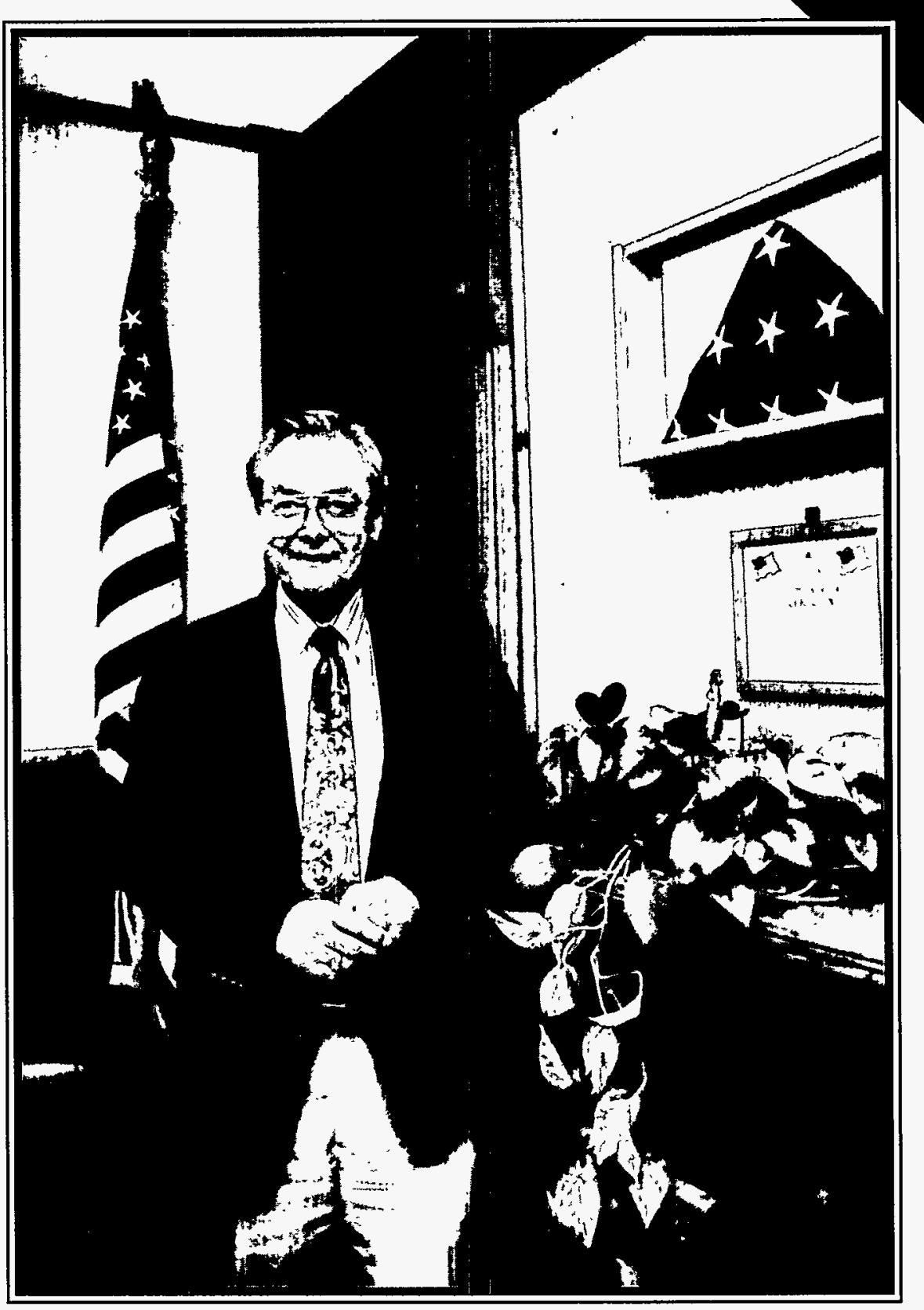
structures of the town, depicts the quality and stability of the community, its founders and its future. 
The Energy
Bende
the

Terry Helton and John Bartel

Hermann, Missouri

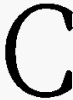

rossing the Highway 19 bridge over the Missouri River, the casual observer is transported back in time and space to the "Olde Country" of 17 th century Germany. The visitor is greeted by signs declaring "Wilkommen to Hermann" during four consecutive weekends in October as the town celebrates Oktoberfest.

Brick sidewalks, laid in a herringbone pattern, pass restored residential homes. Per capita, Hermann contains the most buildings listed on the National Register of Historic Places as designated by the U. S. Department of the Interior.

The first settlers came to Missouri from Philadelphia to protect their old country ways and the German language. Today, the town is a far cry from the wilderness that greeted the first arrivals. The European atmosphere, ethnic foods, vineyards and wineries in the area help to

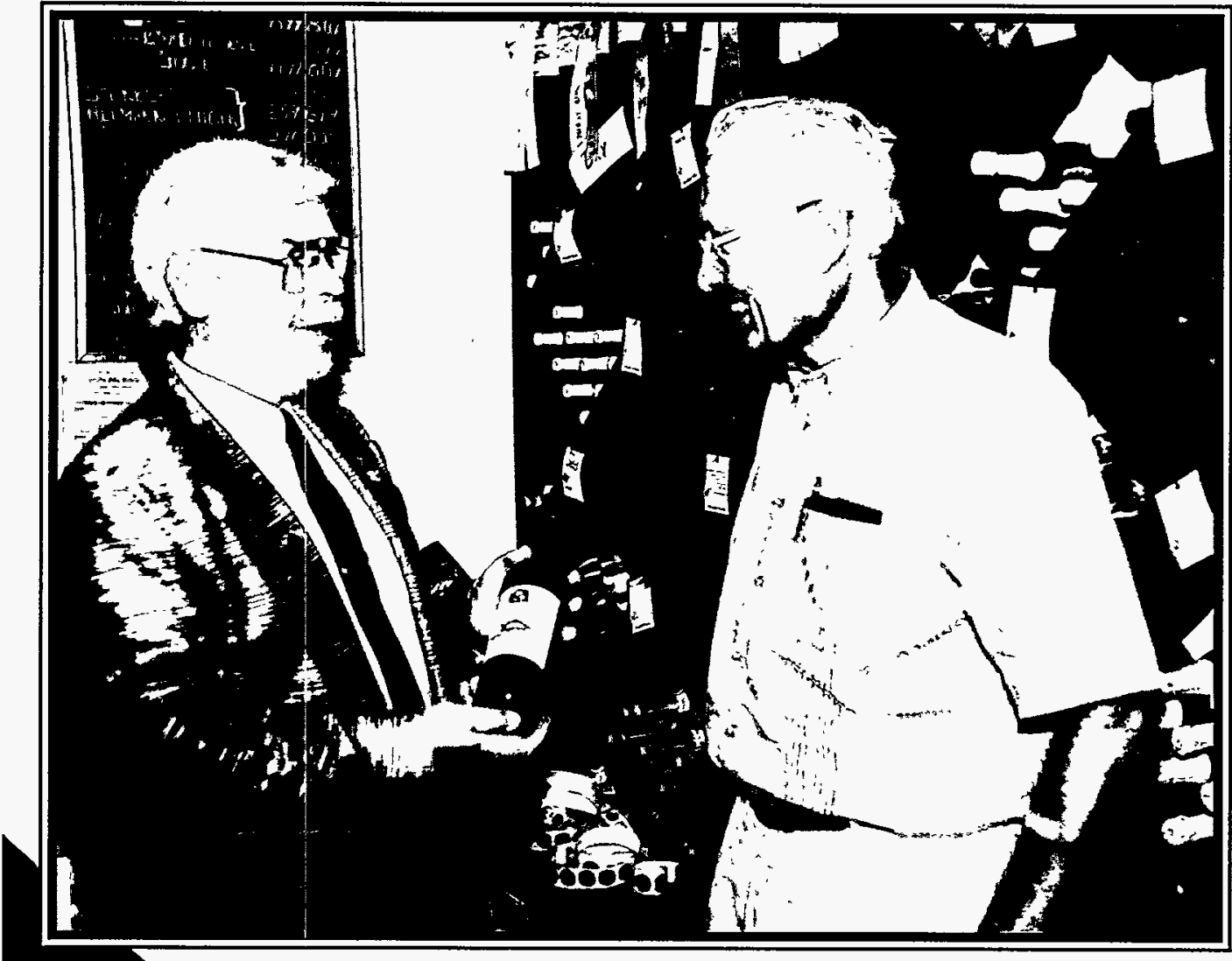
preserve the culture and heritage of the people and their forebearers.

Many of the tourists come to Hermann to research their German genealogy. The Oktoberfest celebration dates back to 1848 when a weinfest was organized to celebrate the area's first large yield of grapes. This became an annual event until Prohibition put an end to all winery activity in 1920.

Terry Helton, Hermann's City

Manager, (above left) notes that the city will spend more than $\$ 3$ million over the next few years to replace and modernize its electrical distribution system. The system provides service through approximately 1,200 electric meters in the town. Mayor John Bartel (pictured right) remarks that the only thing wrong with the power from Southwestern is "there is just not enough of it!" 


\section{YEAR IN REVIEW}

\section{Percent variance of actual from planned and annual principal payments}

This measure provides direct information as to the Agency's ability to meet its planned payments to the U.S. Treasury in any given year. As with other indicators that are influenced by current period revenues, a

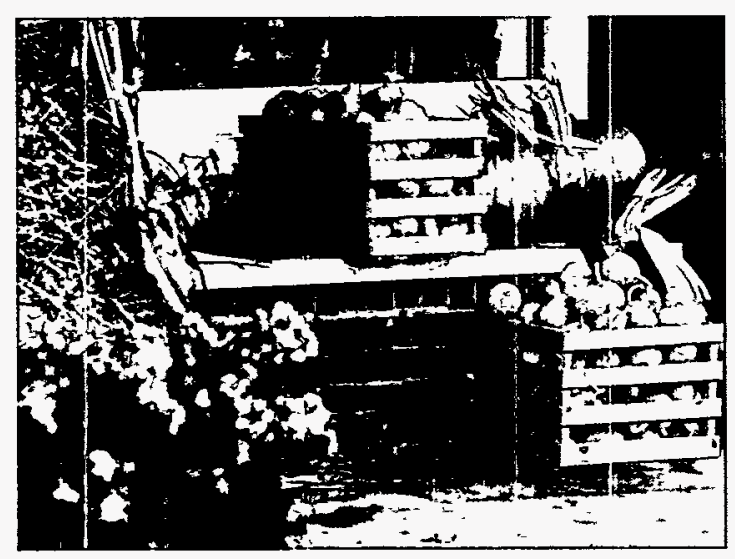
substantial variability will result in the amount of annual revenues being applied due to the variability caused primarily by water conditions of hydro-based systems.

Five-year Analysis: The variances cited above show that the Agency's ability to match its planned principal payments is directly and significantly impacted by water conditions.

\section{Net cash flow to the Treasury}

This provides a measure of, among other things, the actual net cash flows (inflows less outflows) to the U.S. Treasury for a fiscal year. It provides a measure of either a cash sufficiency or deficiency. Variations in annual expenses and water conditions have a diluting impact on the efficiency of the measurement. Therefore, this measure should be used in conjunction with the other financial measures listed above to evaluate financial performances.

Five-year Analysis: In each of the past five years, Southwestern has been able to provide for the U.S. Treasury a positive net cash flow.

\section{Program Performance Measures}

Southwestern Power Administration's Program Performance Measures of Transmission System and Environmental Program Performance Measures were developed for the first time in fiscal year 1992. Therefore, the only established baseline to historically evaluate these performance measures is a three-year comparison. However, Southwestern plans to establish benchmarks for each program category for maximum effectiveness in evaluating performance.

\section{1 ransmission System}

\section{Performance}

\section{Occupational Health and Safety Measures}

\section{Lost work day case rate}

This rate represents a ratio of the number of days away from work compared to total man-hours worked per year. This measure was established by the Bureau of Labor Statistics. Southwestern's rate for 1994 was 2.59 cases per 100 employees compared to 2.24 and 2.60 cases in 1993 and 1992, respectively. 


\section{Total recordable case rate}

This rate represents a ratio of the number of all work-related injuries which result in loss of consciousness, restrictions of work or motion, transfer to another job, or medical treatment beyond first aid compared to the total man hours worked. This measure was established by the Bureau of Labor Statistics. Southwestern's rate in 1994 was 4.14 cases per 100 employees compared to 7.27 and 3.12 cases in 1993 and 1992, respectively.

\section{Motor vehicle accident rate}

This rate represents a ratio of all work-related motor vehicle accidents compared to the total vehicle miles driven. Southwestern's rate in 1994 was 3.67 accidents per one million miles driven compared to 4.93 and zero in 1993 and 1992, respectively.

\section{Transmission System}

\section{Transmission system performance index}

Transmission system reliability is a fundamental requirement of every electrical utility operation to provide the desired electrical services. Determination of reliability is complex. Southwestern is monitoring criteria established by the North America Electric Reliability Council in an effort to measure this complex issue. The criteria in 1994 was identified as matching generation with its load obligation. In 1994, Southwestern had a 96.5 performance index, identical to 96.5 percent reported in both 1993 and 1992.

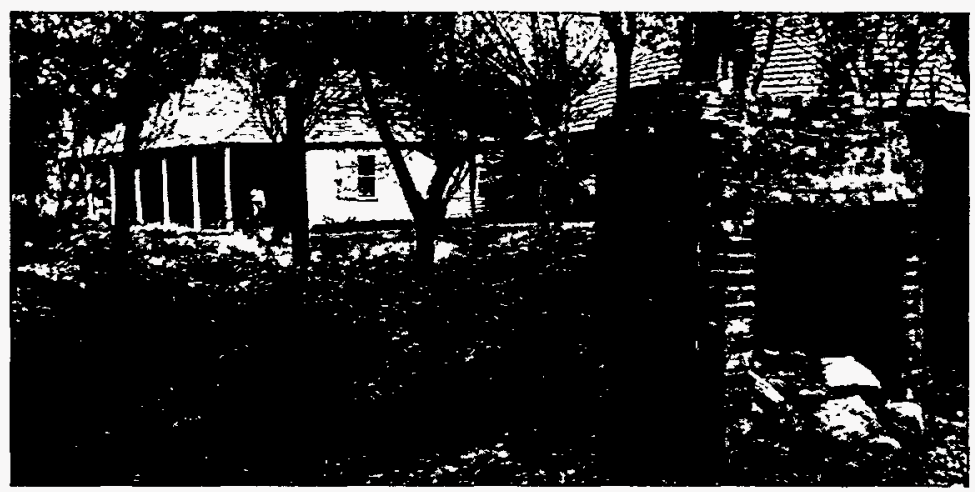

\section{Environmental Performance}

\section{Total pounds of Polychlorinated Biphenyl (PCB) disposed}

While maintaining a competitive ability to serve Southwestern's customers, the mission must be completed in an environmentally safe manner. Disposal of any contaminated substances will be completed in a prompt and efficient manner. Southwestern will track this environmentally related information for compliance goals. Disposal of PCB-contaminated substances by Southwestern at a disposal facility approved by the Environmental Protection Agency amounted to 3,744 kilograms (8,246 pounds) in 1994 compared to 950 kilograms (2,093 pounds) and 425 kilograms (935 pounds) in 1993 and 1992, respectively. 


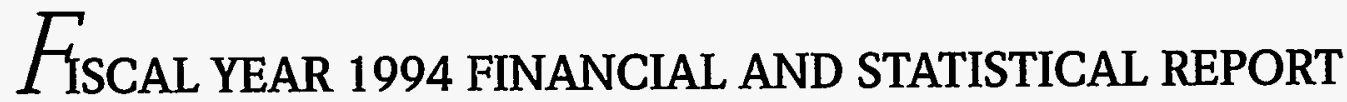

\section{Summary of Results}

Southwestern credited $\$ 32.2$ million to repayment in FY 1994 raising cumulative repayment of investment to $\$ 329.9$ million. This represents 33 percent of the total investment.

Southwestern's objectives are to:

- repay the initial power investment in each power project within 50 years of the project's on-line date (the start of commercial generation);

- repay the cost of each portion of the transmission system within 45 years of construction;

- repay the cost of replacements of such equipment within the service life of the equipment; and

- pay all costs associated with the operation and maintenance of the projects and the transmission system.

\section{Annual and Cumulative Repayment of Capital Investment}

millions of doliars

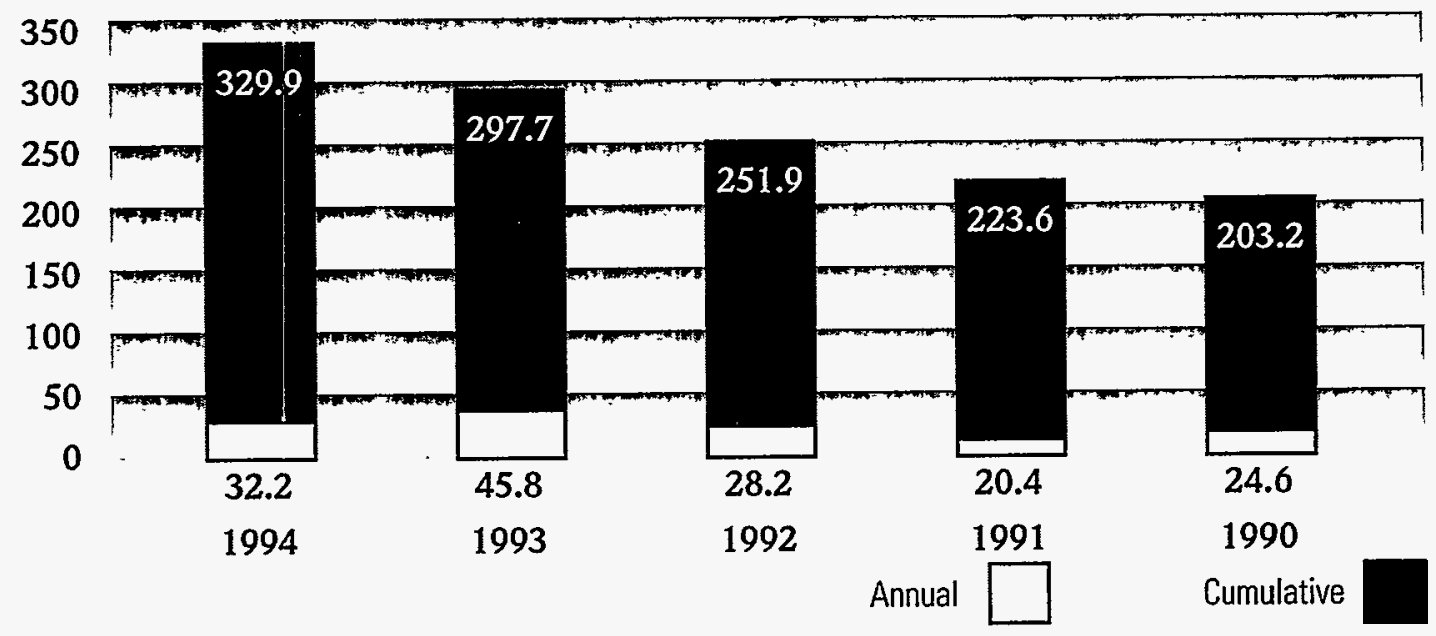

\section{Energy Generation}

By month - millions of kilowatthours

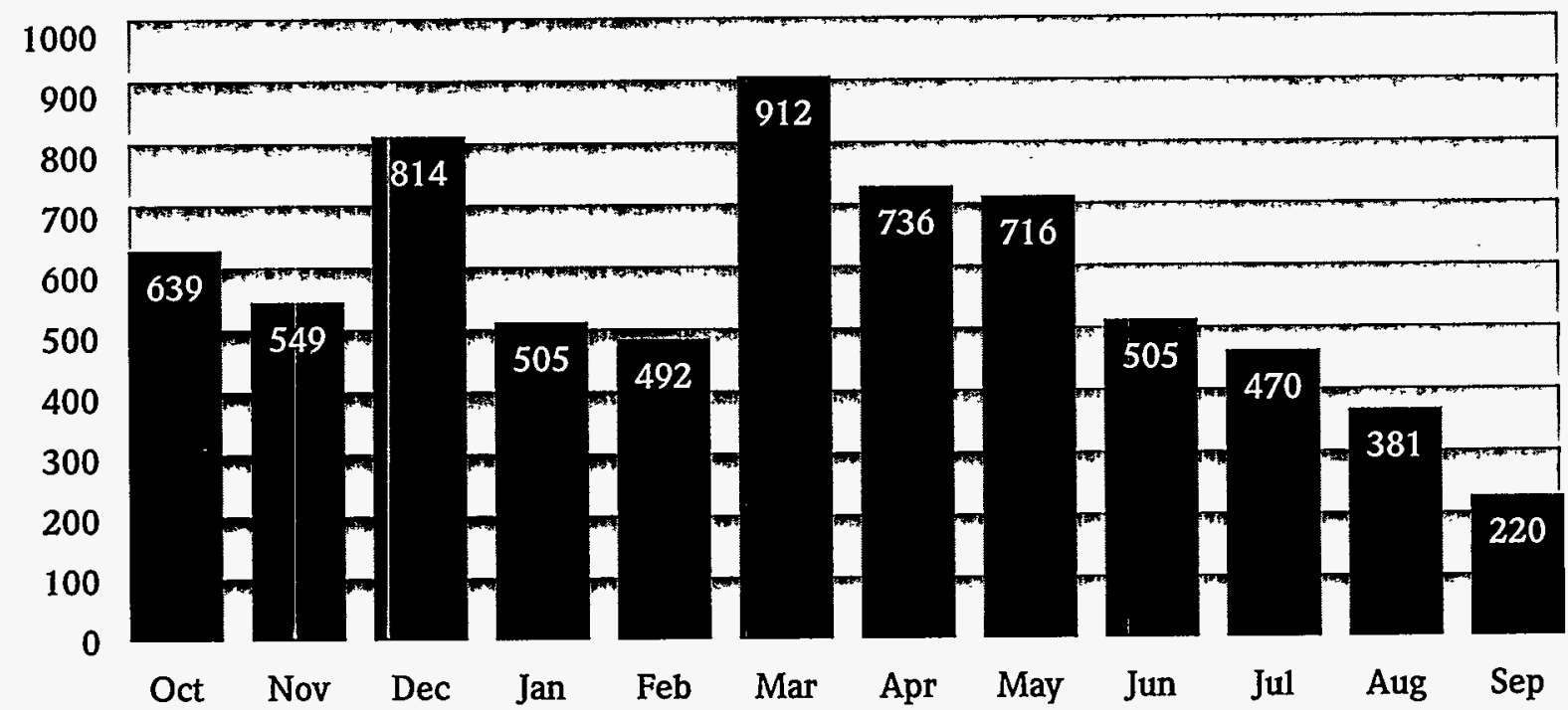


During FY 1995, the initial power investment in Southwestern's first power projects, Norfork and Denison, will be fully repaid. Initial power investment in the most recent of Southwestern's projects, Clarence Cannon, will be fully repaid by FY 2036. Initial capital costs of the Robert D. Willis project, which came on-line in FY 1990, were paid in advance by the non-Federal sponsor, the Sam Rayburn Municipal Power Agency.

The net energy production of 6,939 gigawatthours was well above the average generation of 5,570 gigawatthours.

Fiscal year 1994 again brought favorable water conditions with June through September below average and the rest of the year above average. Although most of the "extra" energy was sold as supplemental energy, Southwestern did make a net deposit of 105 gigawatthours into its "energy banks" during fiscal year 1994 to end the year with 1,759 gigawatthours of "banked energy."

\section{Discretionary Energy Distribution and Banking Activity}

By month - millions of kilowatthours

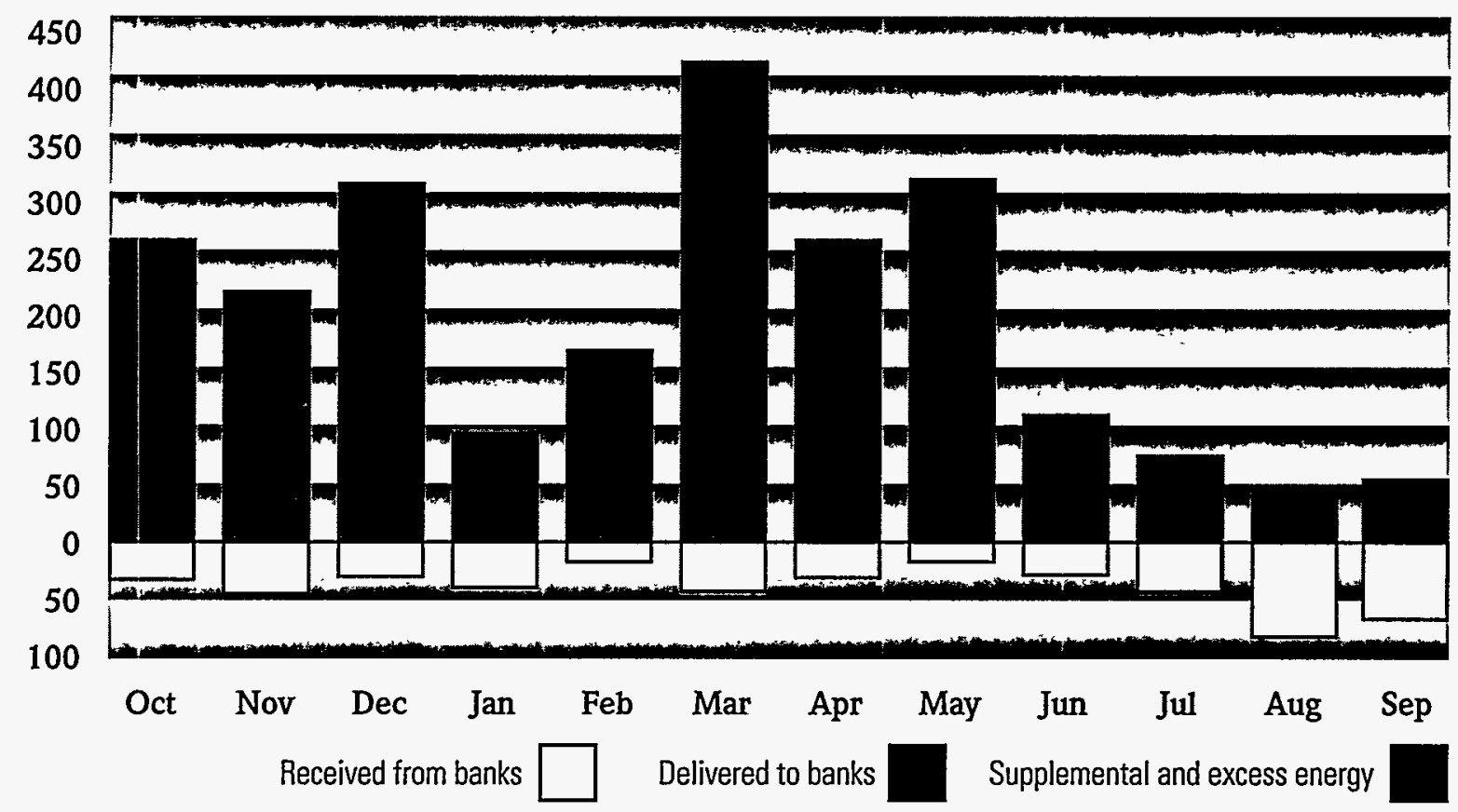

\section{Historical Hydroelectric Energy Generation}

By year - billions of kilowatthours

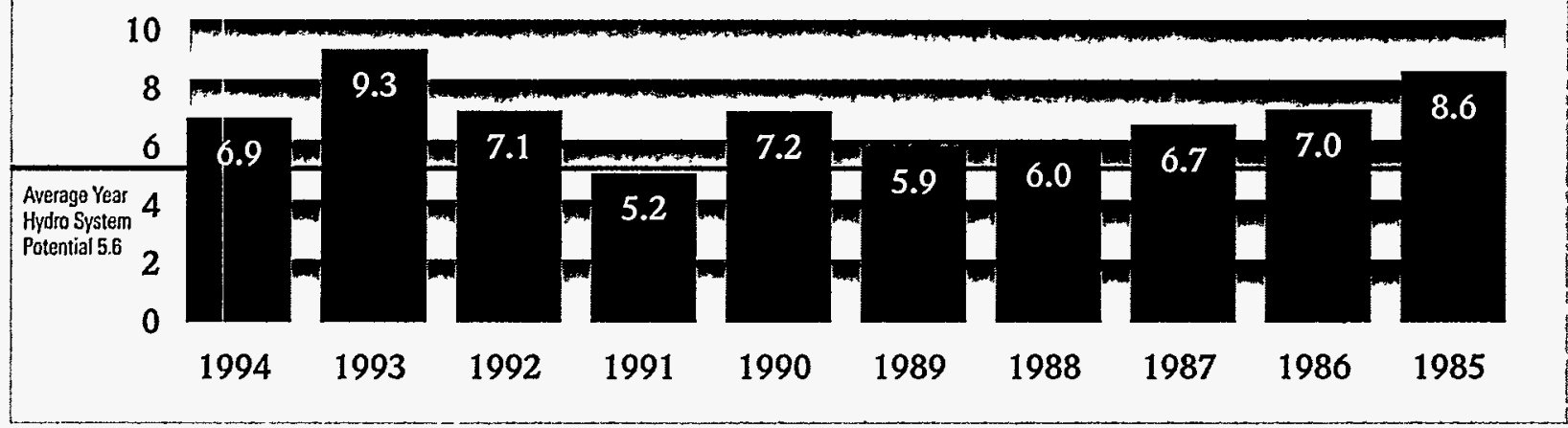




\section{FINANCIAL AND STATISTICAL REPORT}

\section{Revenues and Expenses}

Revenues for FY 1994 were $\$ 109.4$ million compared to $\$ 115.7$ million in FY 1993. Expenses, excluding depreciation, were $\$ 76.1$ million of which $\$ 18$ million was payment of interest on the investment. The net revenue, which was applied to repayment of the principal, was $\$ 32.2$ million.

\section{Annual Revenues and Expenses}

millions of dollars

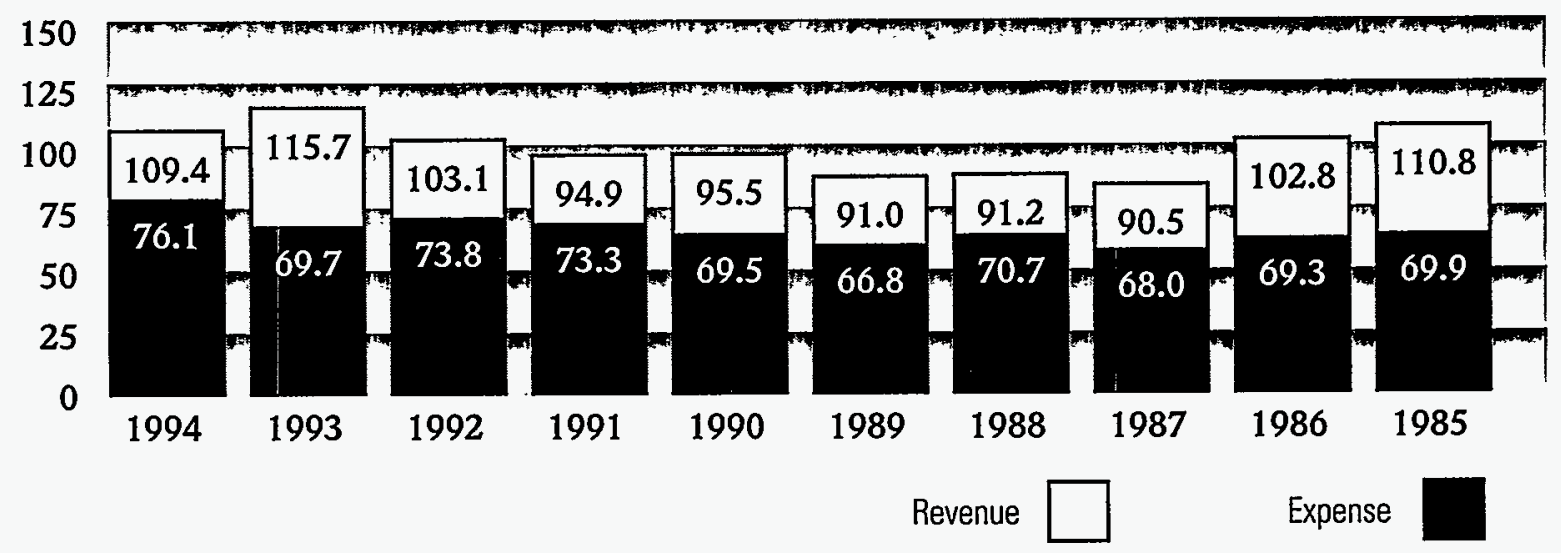

\section{Net Hydropower Generation}

By month - millions of kilowatthours

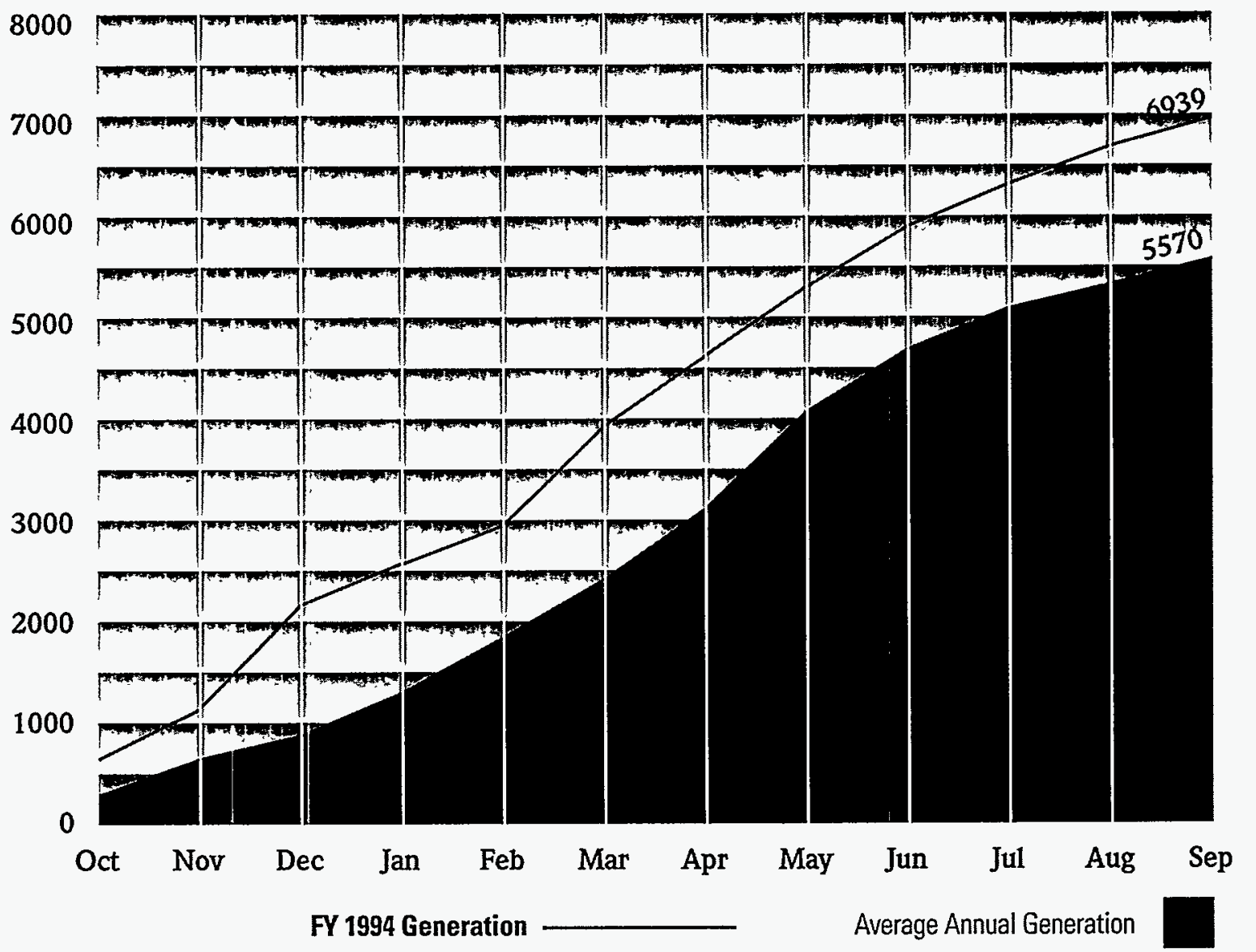


Federal Investment in Generating and Transmission Facilities in Service

1994

1993

Generating facilities

Transmission facilities

Total Investment

$$
\begin{aligned}
& \begin{array}{l}
\$ 917,623,213 \quad \$ 913,134,749
\end{array} \\
& \frac{120,109,786}{\$ 1,037,732,999} \quad \frac{112,486,666}{\$ 1,025,621,415}
\end{aligned}
$$

Adjustments:

Retirement work-in-progress

$$
\begin{array}{rr}
\begin{array}{r}
94,123 \\
(30,190,906) \\
\end{array} & (28,941,423) \\
\cline { 2 - 2 } & \$ 996,784,423 \\
\hline
\end{array}
$$

Truman adjustment*

Total repayable

investment

${ }^{\star}$ Adjustment reflecting Harry S. Truman's limited operating conditions and interim cost allocation rates.

\section{Cumulative Repayment Status}

Robert D. Willis Sam Rayburn Integrated System Total SWFPS

Revenues

$\$ 1,723,800$

$\$ 38,330,894$

$\$ 2,111,452,193$

$\$ 2,151,506,887$

Expenses

Operations and Maintenance

$$
1,526,467
$$

$$
13,986,082
$$

$$
721,411,888
$$

$736,924,437$

Purchased power and

service charge

Interest

Total expenses

Revenue applied to amortization

(Cumulative status of repayment)

Total unpaid investment

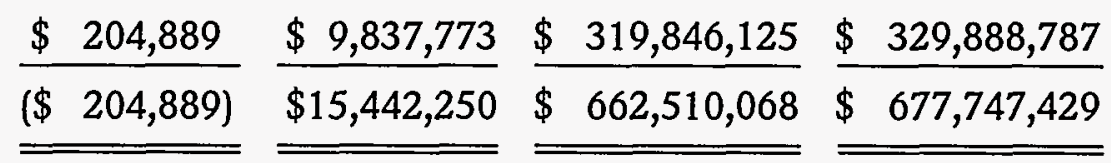




\section{$\prod_{\text {EN YEAR STATISTICAL SUMMARY* }}$}

Revenue

1994

1993

1992

1991

Annual gross revenue

Annual expense other than depreciation

Net (deficiency) revenues available for repayment

Less: Retirement losses

Cost allocation adjustment

Amount available for repayment

$\$ 109,403,515$

$76,131,389$

$\$ 33,272,126$

$(1,067,273)$

$(197,259)$

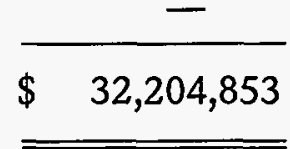

$\$ 45,830,236$

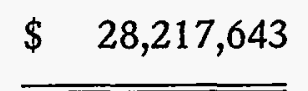

$(1,076,739)$

$(1,122,841)$

Repayable Investment

$$
\begin{aligned}
& \text { Generation } \\
& \text { Transmission } \\
& \text { Total repayable investment } \\
& \quad \text { in completed plant }
\end{aligned}
$$

System Statistics

44 Total number of plants

(hydro projects)

24

24

24

24

Number of kilometers

of transmission line

Generating capacity (MW)

2,220

2,220

2,220

2,220

2,158

2,158

2,158

2,158

Cost of generating plant investment per $\mathrm{kW}$

$\$ 410$

$\$ 410$

$\$ 409$

$\$ 407$

Number of customers

94

96

95

94

Number of full-time

equivalent $(\mathrm{FTE})^{\star \star \star}$

\begin{tabular}{|c|c|c|c|c|c|}
\hline \multicolumn{6}{|c|}{$\begin{array}{l}\text { Source and Disposition of Energy } \\
\text { Fiscal Year } 1994\end{array}$} \\
\hline Where it Came From & $\begin{array}{r}\text { Millions } \\
\text { kWh }\end{array}$ & $\%$ & Where it Went & $\begin{array}{r}\text { Millions } \\
\text { kWh }\end{array}$ & $\%$ \\
\hline Direct purchase & 0 & 0.0 & Losses & 134.9 & 1.8 \\
\hline Interchange & 436.4 & 5.9 & Interchange & 537.2 & 7.2 \\
\hline Borderline purchases & 55.7 & 0.7 & Contract exchange & 179.1 & 2.4 \\
\hline Generated by hydro- & & & Municipalities & $1,742.2$ & 23.5 \\
\hline electric plants of & & & Government agencies & 187.4 & 2.5 \\
\hline U.S. Army Corps & & & Cooperatives & $4,649.8$ & 62.6 \\
\hline of Engineers & $6,938.8$ & 93.4 & Investor owned utility & 0.3 & 0.0 \\
\hline Total & $\overline{7,430.9}$ & $\overline{100.0}$ & Total & $\overline{7,430.9}$ & $\overline{100.0}$ \\
\hline
\end{tabular}


SOUTHWESTERN FEDERAL POWER SYSTEM

1990

1989

1988

1987

1986

1985

\begin{tabular}{|c|c|c|c|c|c|c|}
\hline $\begin{array}{r}95,460,791 \\
(69,519,811)\end{array}$ & $\$$ & $\begin{array}{r}91,006,581 \\
(66,774,205)\end{array}$ & $\begin{array}{r}\$ 91,226,822 \\
(70,732,940)\end{array}$ & $\begin{array}{r}\$ 90,561,574 \\
(68,001,438)\end{array}$ & $\begin{array}{r}\$ 102,825,673 \\
(69,298,943)\end{array}$ & $\begin{array}{r}\$ 110,786,760 \\
(69,855,372)\end{array}$ \\
\hline $25,940,980$ & $\$$ & $24,232,376$ & $\$ 20,493,882$ & $\$ 22,560,136$ & $\$ 33,526,730$ & $\$ 40,931,388$ \\
\hline$(1,365,527)$ & & $(552,722)$ & $(262,133)$ & $(2,095,097)$ & $(3,480,182)$ & $(3,301,183)$ \\
\hline - & & - & 一 & 一 & $(88,355)$ & $(6,694,664)$ \\
\hline $24,575,453$ & $\$$ & $23,679,654$ & $\$ 20,231,749$ & $\$ 20,465,039$ & $\$ 29,958,193$ & $\$ 30,935,541$ \\
\hline
\end{tabular}

\begin{tabular}{|c|c|c|c|c|c|}
\hline $1,730,097$ & $\$ 867,763,880$ & $\$ 860,096,340$ & $\$ 854,803,680$ & $\$ 851,619,613$ & $\$ 835,179,264$ \\
\hline $89,465,988$ & $83,411,218$ & $81,134,595$ & $76,744,225$ & $70,018,954$ & $67,866,477$ \\
\hline & $\$ 951,175,098$ & $\$ 941,230,935$ & $\$ 931,547,905$ & $\$ 921,638,567$ & $\$ 903,045,741$ \\
\hline
\end{tabular}

45

\begin{tabular}{|c|c|c|c|c|c|}
\hline 24 & 23 & 23 & 23 & 23 & 23 \\
\hline 2,220 & 2,220 & 2,220 & 2,220 & 2,220 & 2,220 \\
\hline 2,158 & 2,150 & 2,150 & 2,150 & 2,150 & 2,150 \\
\hline$\$ 404$ & $\$ 404$ & $\$ 400$ & $\$ 398$ & $\$ 396$ & $\$ 388$ \\
\hline 94 & 95 & 93 & 93 & 93 & 58 \\
\hline 184 & 195 & 192 & 193 & 193 & 186.5 \\
\hline \multicolumn{6}{|c|}{$\begin{array}{l}\text { Source and Disposition of Revenue Dollar } \\
\text { Fiscal Year } 1994\end{array}$} \\
\hline Where it Came From & $\$ 000$ & $\%$ & $\begin{array}{l}\text { Where it Went } \\
\text { Available for repayment }\end{array}$ & $\begin{array}{r}\$ 000 \\
32,205\end{array}$ & $\begin{array}{r}\% \\
29.5\end{array}$ \\
\hline Miscellaneous & 3,322 & 3.0 & Interest expense & 18,097 & 16.5 \\
\hline Deferred revenue & 1,502 & 1.4 & Purchased power & & \\
\hline Investor owned utility & 2 & 0.0 & and bank exchange & 7,752 & 7.1 \\
\hline Government agencies & 4,347 & 4.0 & Transmission & & \\
\hline Municipalities & 27,055 & 24.7 & service charge & 2,645 & 2.4 \\
\hline Cooperatives & 66,795 & 61.1 & Operations, maintenance & & \\
\hline Banking exchange & 6,381 & 5.8 & \& other ${ }^{* \star}$ & 48,705 & 44.5 \\
\hline Total & $\overline{109,404}$ & $\overline{100.0}$ & Total & $\overline{109,404}$ & $\overline{100.0}$ \\
\hline
\end{tabular}

Source and Disposition of Revenue Dollar

Fiscal Year 1994
*The Financial Statistical Summary has been restated to reflect data used in Southwestern's Power Repayment Studies which include prior years' adjustments.

$\star \star$ Includes losses on retirement of assets booked through the depreciation reserve.

$\star \star \star$ Beginning 1994 , student employees are included in

FTE totals. 


\section{Power and financial data summary}

September 30, 1994

\begin{tabular}{|c|c|c|c|c|}
\hline Project & $\begin{array}{c}\mathrm{FY} \\
\text { On-Line } \\
\text { Date }\end{array}$ & $\begin{array}{c}\text { Installed } \\
\text { Capacity } \\
\text { kW }\end{array}$ & $\begin{array}{l}\text { Est. Average } \\
\text { Annual Energy } \\
\text { (million kWh) }\end{array}$ & $\begin{array}{l}\text { Net Energy } \\
\text { Production } \\
\text { (million } \mathrm{kWh} \text { ) }\end{array}$ \\
\hline Beaver (AR) & 1965 & 112,000 & 172 & 181 \\
\hline Blakely Mountain (AR) & 1956 & 75,000 & 169 & 206 \\
\hline Broken Bow (OK) & 1070 & 100,000 & 129 & 190 \\
\hline Bull Shoals (AR) & 1953 & 340,000 & 785 & 1,223 \\
\hline Clarence Cannon (MO) & 1985 & 58,000 & 90 & 148 \\
\hline Dardanelle (AR) & 1965 & 124,000 & 613 & 667 \\
\hline DeGray (AR) & 1972 & 68,000 & 97 & 99 \\
\hline Denison $(\mathrm{OK} / \mathrm{TX})$ & 1945 & 70,000 & 219 & 296 \\
\hline Eufaula $(\mathrm{OK})$ & 1965 & 90,000 & 260 & 248 \\
\hline Ft. Gibson (OK) & 1953 & 45,000 & 191 & 243 \\
\hline Greers Ferry (AR) & 1964 & 96,000 & 189 & 179 \\
\hline Harry S. Truman (MO) & 1982 & $* 160,000$ & 244 & 229 \\
\hline Keystone (OK) & 1968 & 70,000 & 228 & 192 \\
\hline Narrows (AR) & 1950 & 25,500 & 30 & 46 \\
\hline Norfork (AR) & 1944 & 80,550 & 184 & 345 \\
\hline Ozark (AR) & 1973 & 100,000 & 429 & 324 \\
\hline Robert D. Willis (TX) & 1989 & 7,350 & 37 & 43 \\
\hline Robert S. Kerr (OK) & 1971 & 110,000 & 459 & 587 \\
\hline Sam Rayburn (TX) & 1966 & 52,000 & 114 & 104 \\
\hline Stockton (MO) & 1973 & 45,200 & 55 & 113 \\
\hline Table Rock (MO) & 1959 & 200,000 & 495 & 819 \\
\hline Tenkiller Ferry (OK) & 1954 & 39,100 & 95 & 157 \\
\hline Webbers Falls (OK) & 1974 & 60,000 & 213 & 258 \\
\hline Whitney (TX) & 1955 & 30,000 & 73 & 42 \\
\hline Totals & & $2,157,700$ & 5,570 & 6,939 \\
\hline
\end{tabular}


Cost

Total

Percent Cost

Project

Assigned

Project

Assigned

to Power *

Cost $^{\star \star}$

to Power

\$ $38,796,884$

$27,308,811$

$25,081,487$

$70,109,538$

$108,337,397$

$46,772,401$

$23,256,801$

$23,300,642$

$37,264,610$

$17,564,261$

$36,049,640$

$157,385,454$

$28,083,225$

$7,925,400$

$18,279,236$

$52,758,928$

6,913

$45,717,383$

$25,595,655$

$19,495,180$

$58,835,535$

$13,333,413$

$34,429,758$

$10,671,839$
\$ $56,173,635$

$43,437,670$

$46,931,984$

$107,013,028$

$378,232,044$

$95,851,828$

$77,695,562$

$73,925,195$

$136,905,256$

$47,726,911$

$56,508,086$

$622,864,997$

$130,797,678$

$20,161,587$

$75,050,845$

$101,408,745$

$8,239,255$

$106,968,033$

$84,758,668$

$87,091,475$

$79,959,816$

$27,796,548$

$98,233,556$

$52,090,290$
$69.1 \%$

$62.9 \%$

$53.4 \%$

$65.5 \%$

$28.6 \%$

$48.8 \%$

$29.9 \%$

$31.5 \%$

$27.2 \%$

$36.8 \%$

$63.8 \%$

$25.3 \%$

$21.5 \%$

$39.3 \%$

$24.4 \%$

$52.0 \%$

$0.1 \%$

$42.7 \%$

$30.2 \%$

$22.4 \%$

$73.6 \%$

$48.0 \%$

$35.0 \%$

$20.5 \%$

$35.4 \%$
Beaver (AR)

Blakely Mountain (AR)

Broken Bow (OK)

Bull Shoals (AR) .

Clarence Cannon (MO)

Dardanelle (AR)

DeGray (AR)

Denison (OK/TX)

Eufaula (OK)

Ft. Gibson (OK)

Greers Ferry (AR)

Harry S. Truman (MO)

Keystone (OK)

Narrows (AR)

Norfork (AR)

Ozark (AR)

Robert D. Willis (TX)

Robert S. Kerr (OK)

Sam Rayburn (TX)

Stockton (MO)

Table Rock (MO)

Tenkiller Ferry (OK)

Webbers Falls (OK)

Whitney (TX)

$\$ 926,360,391$

$\$ 2,615,822,692$

Totals

*Only 53,300 kW have been declared in commercial operation.

**Includes construction work in progress with plant in service less contributions in aid of construction. 


\section{Detall of power sales}

Fiscal Year 1994

Customer

\section{Cooperatives}

Arkansas Electric Cooperative Corporation

Associated Electric Cooperative, Inc.

Brazos Electric Power Cooperative, Inc.

Cajun Electric Power Cooperative, Inc.

Kansas Electric Power Cooperative, Inc.

Kaw Valley Electric Cooperative, Inc.

Northeast Texas Electric Cooperative, Inc.

Rayburn Country Electric Cooperative, Inc.

Sam Rayburn Dam Electric Cooperative, Inc.

Tex-La Electric Cooperative of Texas, Inc.

Western Farmers Electric Cooperative

Total Cooperatives ( 11 customers)

\section{Government Agencies}

Department of the Army, Ft. Sill, OK
36,700
2,688
0
6,600

Total Government Agencies (4 customers)

45,988
Army Ammunition Plant, McAlester, OK

Grand River Dam Authority

Vance Air Force Base, Enid, OK

Municipalities

Anthony, Kansas

Augusta, Arkansas

Bentonville, Arkansas

Carthage, Missouri

Clarksville, Arkansas

Coffeyville, Kansas

Comanche, Oklahoma

Copan, Oklahoma

Duncan, Oklahoma

Eldorado, Oklahoma

Fulton, Missouri

Goltry, Oklahoma

Granite, Oklahoma

Hermann, Missouri

Higginsville, Missouri

Hominy, Oklahoma

Jonesboro, Arkansas

Kansas City, Kansas
Capacity
$\mathrm{kW}$

Energy

Delivered

(000) kWh

189,000

519,000

35,200

91,400

100,000

1,000

127,500

44,100

52,000

28,200

260,000

$1,447,400$

300

3,700

18,000

7,000

19,100

1,900

4,200

2,500

32,500

1,300

3,000

900

2,300

5,800

3,000

10,000

80,000

38,600

515,966
$2,029,204$
56,743
279,890
279,547
2,713
324,895
183,146
104,361
117,506
755,825

$4,649,796$

158,820

9,392

1,130

18,019

187,361

881

10,773

53,100

20,480

55,156

5,229

12,055

7,176

93,282

3,731

8,950

2,564

6,602

16,091

8,800

28,702

235,858

110,134
Revenue

from

Power Sales

(Dollars)

$\$ 8,120,406$

$26,246,421$

$1,351,824$

$4,084,046$

$4,328,006$

42,867

$5,393,176$

$2,283,546$

$2,076,444$

$1,462,753$

$11,405,920$

$\$ 66,795,409$

$\$ 3,780,334$

233,979

5,876

327,007

$\$ 4,347,196$

$\$ \quad 13,210$

162,346

793,470

317,803

836,026

81,841

211,289

125,425

$1,634,973$

65,399

132,205

45,184

115,706

251,174

132,034

503,069

$3,526,142$

$1,678,542$ 
Customer

Lexington, Oklahoma

Louisiana Energy \& Power Authority

(Serves 10 municipals)

Malden, Missouri

Manitou, Oklahoma

Natchitoches, Louisiana

New Madrid, Missouri

Nixa, Missouri

Olustee, Oklahoma

Paragould, Arkansas

Paris, Arkansas

Piggott, Arkansas

Poplar Bluff, Missouri

Purcell, Oklahoma

Ryan, Oklahoma

Sam Rayburn Municipal Power Agency

Sikeston, Missouri

Skiatook, Oklahoma

Spiro, Oklahoma

Springfield, Missouri

Thayer, Missouri

Walters, Oklahoma

West Plains, Missouri

Wetumka, Oklahoma

Yale, Oklahoma

Total Municipalities (78 customers)

\section{Utility Companies*}

Empire District Electric Company

Total Utility Companies ( 1 customer)

Total Southwestern Sales of

Electric Power and Energy (94 customers)
Capacity

kW

11,200

11,000

18,000

12,000

4,100

Energy

Delivered

$(000) \mathrm{kWh}$

31,400

5,000

600

2,500

4,500

5,300

700

50,500

10,800

4,900

39,500

14,500

1,900

7,350

33,800

11,00

4,000

50,000

2,800

6,400

15,000

2,600

3,700

599,150

0

0

90,418

14,772

1,159

5,288

12,879

15,543

2,009

150,020

29,485

14,757

118,890

39,587

5,453

43,328

92,283

32,252

11,394

146,627

7,889

18,369

41,062

7,463

10,539

$1,742,174$

$\begin{array}{lll}34,303 & \$ & 500,331 \\ 33,158 & & 504,460 \\ 38,074 & & 715,718 \\ 33,930 & & 522,723 \\ 11,679 & & 205,839\end{array}$

$\$ 27,054,771$

$1,373,508$

227,755

36,229

99,405

203,258

240,746

35,215

$2,304,372$

535,102

250,005

$1,809,845$

718,424

95,583

284,580

$1,455,177$

483,982

200,818

$2,199,160$

121,514

321,964

667,949

129,514

185,757

$2,092,538 \quad 6,579,581 \quad \$ 98,198,676$ 


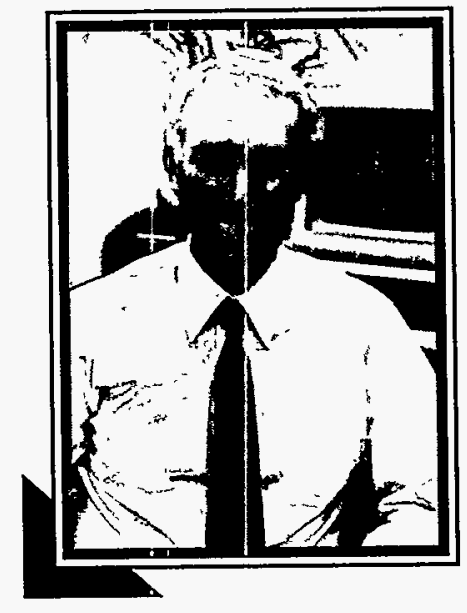

50

Remembering

\section{Fred Munsell}

Public Utilities Specialist

Chairman, White River Dissolved Oxygen Committee

"Helping people to be the best they could possibly be..."

1946 - 1994

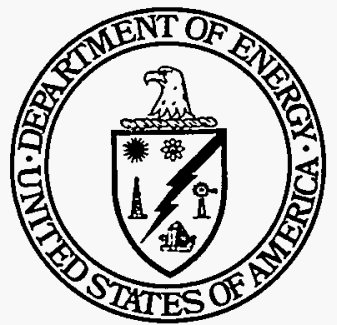

DOE/SWPA-9501

Department of Energy

Southwestern Power

Administration

P.O. Box 1619

Tulsa, Oklahoma 74101-1619

918/581-7474

Springield

Maintenance

P.O. Box 3336

Springfield, Missouri 65808-3336

$417 / 881-8772$

Springfield

Operations

P.O. Box 10284

Springfield, Missouri 65808-0284

417/881-1820

Jonesboro

Maintenance

P.O. Box 1223

Jonesboro, Arkansas 72402-1223

501/972-4686

Tupelo

Maintenance

P.O. Box 240

Tupelo, Oklahoma 74572-0240 405/845-2471

Gore

Maintenance

P.O. Box 728

Gore, Oklahoma 74435-0728

405/489-5582 


\section{SOUTHWESTERN}

\section{POWER}

\section{ADMINISTRATION \\ ORGANIZATION}

Acting Administrator

Forrest E. Reeves

Special Assistant to the Administrator

Francis R. Gajan

Chief Counsel

Charles A. Borchardt

Acting Assistant Administrator,

Power Marketing and Delivery

Gerald D. Johnson

Director of Customer Service James K. McDonald

Director of Engineering and Planning Kenneth E. Legg

Acting Director of Scheduling and Operations George E. Robbins

Assistant Administrator, Maintenance Dallas W. Cooper

Special Assistant for Administration, Springfield, MO

James B. Jennings

Director, Engineering and Communications, Springfield, MO and Jonesboro, AR

Otis A. Keller

Director, Transmission, Gore, OK and Tupelo, OK

Thomas J. Green

Assistant Administrator, Administration and Rates and Chief Financial Officer

George C. Grisaffe

Director of Financial Management

Gary L. Swartzlander

Director of Human Resources Management

Colin E. Kelley

Director of Acquisition and Property Joseph M. Malinovsky

Director of Rates and Repayment James W. Sherwood

Director of Information Resources Management Robert F. Purnell, Jr.

Deputy Assistant Administrator

Power Marketing Liaison Office

Rodney L. Adelman

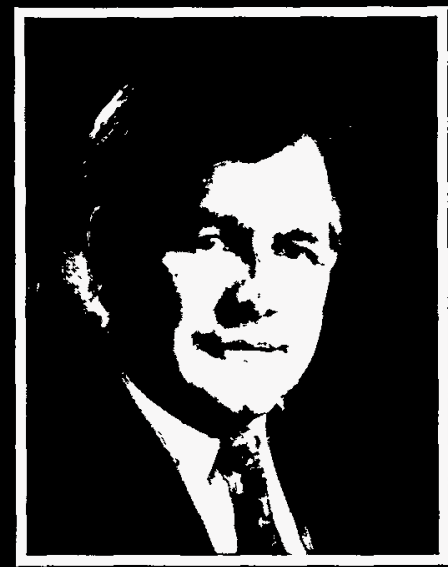

Forrest E. Reeves Acting Administrator

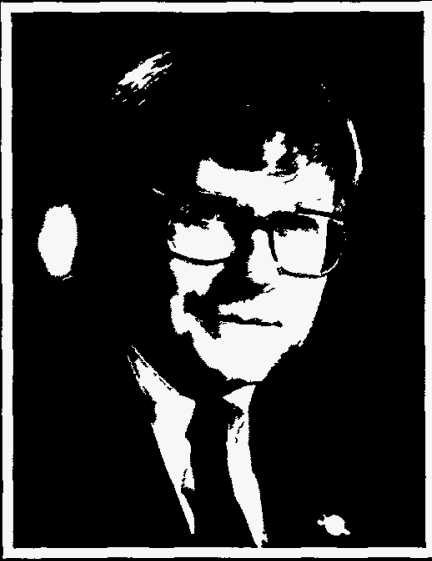

Charles A. Borchardt Chief Counsel

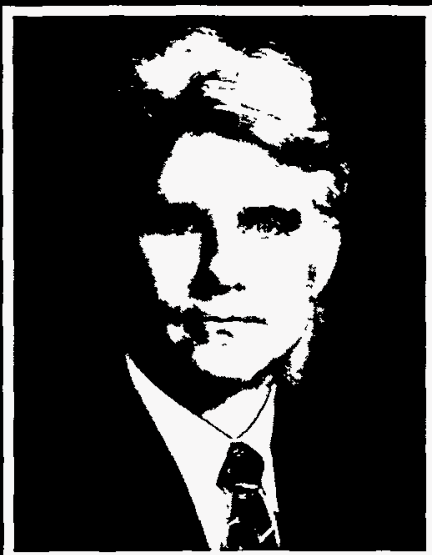

Dallas W. Cooper Assistant Administrator Maintenance

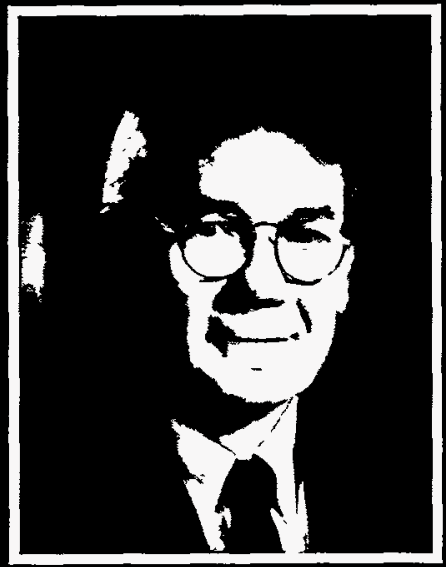

Francis R. Gajan

Special Assistant to the Administrator

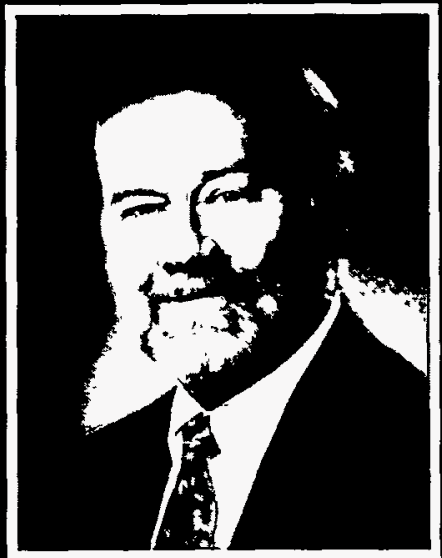

Gerald D. Johnson Acting Assistant Administrator Power Marketing and Delivery

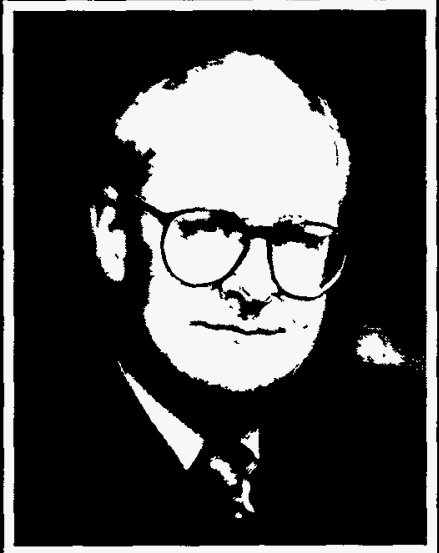

George C. Grisaffe Assistant Administrator Administration and Rates and Chief Financial Officer 


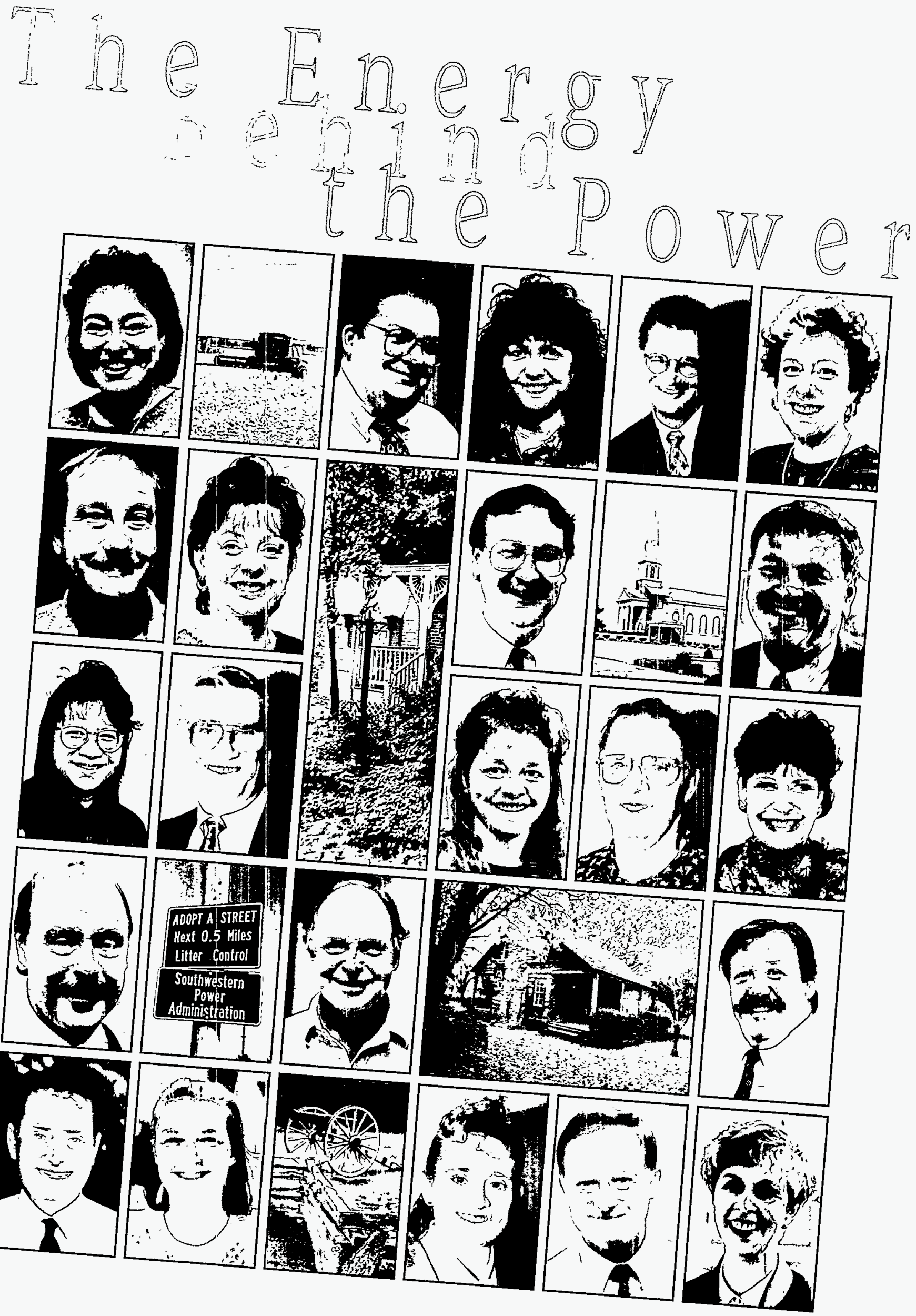

